\title{
Heteroarylnitrones as Drugs for Neurodegenerative Diseases: Synthesis, Neuroprotective Properties, and Free Radical Scavenger Properties
}

\author{
Williams Porcal, ${ }^{\ddagger}$ Paola Hernández, ${ }^{\ddagger}$ Mercedes González, ${ }^{\ddagger}$ Ana Ferreira, ${ }^{\S}$ Claudio Olea-Azar, ${ }^{\#}$ Hugo Cerecetto, ${ }^{*},+$ and \\ Ana Castro*,ll, \\ Departamento de Química Orgánica, Facultad de Ciencias-Facultad de Química, and Catedra de Inmunología, Universidad de la República, \\ Montevideo, Uruguay, Departamento de Química Inorgánica y Analítica, Facultad de Ciencias Químicas y Farmacéuticas, Universidad de \\ Chile, Santiago, Chile, and Instituto de Química Médica (CSIC), Madrid, Spain
}

\begin{abstract}
New 1,2,4-thiadiazolylnitrones and furoxanylnitrones were developed and evaluated as neuroprotective agents on a human neuroblastoma (SH-SY5Y) cells model. They inhibited at low micromolar concentrations the oxidative damage and the death induced by exposure to hydrogen peroxide. These heteroarylnitrones showed excellent peroxyl free radical absorbance capacities, analyzed by oxygen radical absorbance capacity (ORAC) assay with fluorescein as the fluorescent probe, ranging from 1.5- to 16.5-fold the value of the reference nitrone, $\alpha$-phenyl- $N$-tert-butylnitrone (PBN). The electron spin resonance spectroscopy (ESR) demonstrated the ability of these derivatives to directly trap and stabilize oxygen, carbon, and sulfur-centered free radicals. These results demonstrated the potential use of these heteroarylnitrones as neuroprotective agents in preventing the death of cells exposed to enhanced oxidative stress and damage.
\end{abstract}

\section{Introduction}

Reactive oxygen species (ROS) and reactive nitrogen species (RNS) produced by oxidative metabolism are capable of damaging cellular components through molecular modifications to a polyunsaturated membrane's lipids, proteins, and nucleic acids. ${ }^{1,2}$ Much evidence suggests that biological oxidation in the human body generates highly pathogenic ROS and RNS such as hydroxyl free radical $\left({ }^{\circ} \mathrm{OH}\right)$, superoxide anion $\left(\mathrm{O}_{2}{ }^{--}\right)$, peroxynitrite $\left(\mathrm{ONOO}^{-}\right)$, and lipid peroxide free radicals $\left(\mathrm{ROO}^{\circ}\right)$, causing cellular injury. ${ }^{3-5}$ These pathological events have important roles in many degenerative disorders, for example, atherosclerosis, rheumatoid arthritis, and several neurodegenerative diseases such as ischemic conditions, stroke, Parkinson's disease, and Alzheimer's disease. ${ }^{6-8}$ The central nervous system (CNS) is especially sensitive to oxidative damage for reasons such as (a) high use of oxygen during the metabolic process and therefore greater production of ROS, (b) fewer antioxidants defenses than other organs, for example, liver and heart, (c) enrichment in the more easily peroxidable fatty acids, (d) areas with high levels of the $\mathrm{Fe}^{3+}$ /ascorbate pro-oxidant system that reduce $\mathrm{H}_{2} \mathrm{O}_{2}$ to form ${ }^{\circ} \mathrm{OH}$, a potent oxidant. ${ }^{9}$ Recently, it has been reported that $\beta$-amyloid solutions liberate hydrogen peroxide and, subsequently, $\mathrm{OH}$ converted via Fenton's reaction. ${ }^{10}$ Consequently, the search of effective treatments that prevent oxidative stress associated with premature aging and

\footnotetext{
* To whom correspondence should be addressed. Phone: +34 918061130 Fax: +34 918034660. E-mail: acastro@neuropharma.es.

* Departamento de Química Orgánica, Universidad de la República.

${ }^{\S}$ Catedra de Inmunología, Universidad de la República.

\# Universidad de Chile.

"Instituto de Química Médica (CSIC).

${ }^{\dagger}$ Present address: NeuroPharma, S. A.; Avda. de la Industria 52, 28760 Tres Cantos, Madrid, Spain.

a Abbreviations: BBB, blood-brain barrier; DMPO, 5,5-dimethyl-1pyrroline $N$-oxide; FL, fluorescein; FRS, free radical scavenger; HFS, hyperfine splitting; LDH, lactate dehydrogenase; NAC, $N$-acetyl cysteine; ORAC, oxygen radical absorbance capacity; PAMPA, parallel artificial membrane permeation assay; PBL, porcine brain lipid; PBN, $\alpha$-phenyl- $N$ tert-butylnitrone; RP, reduction percentage.
}

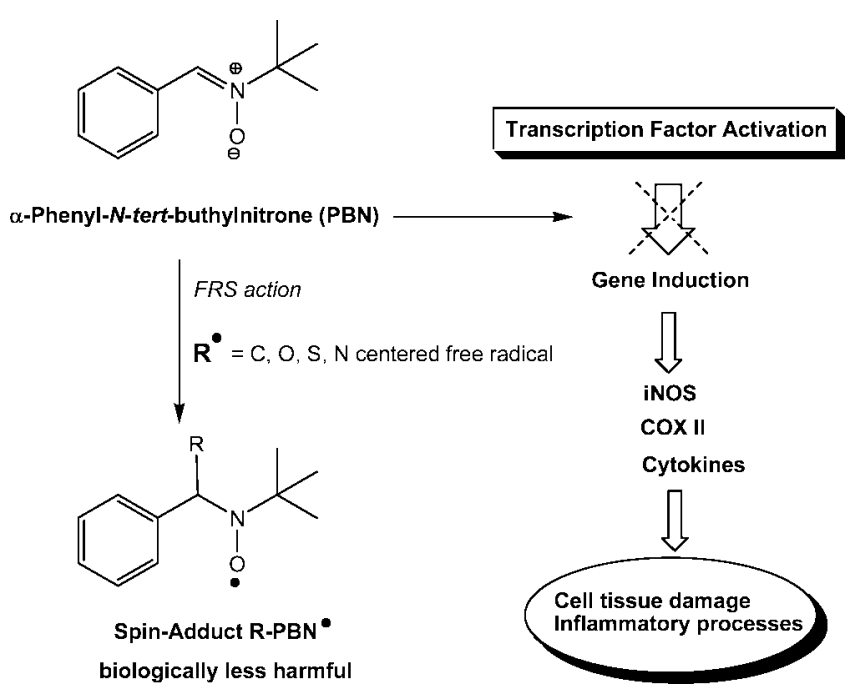

Figure 1. Antioxidant and neuroprotective mechanisms of action postulated for PBN.

neurodegenerative diseases is an important area of neurochemical research.

Recently, it has been proved that nitrone-free radical trap, i.e., $\alpha$-phenyl- $N$-tert-butylnitrone ( $\mathrm{PBN},{ }^{a}$ Figure 1$)$, could be used in the treatment of neurodegenerative diseases as well as in the prolongation of life span. ${ }^{11}$ Initially, the neuroprotective activity was attributed to the nitrone group because of its ability to act as free radical scavenger (FRS, Figure 1). Subsequently, observations that PBN has a good neuroprotective activity at lower doses than those necessary to act as an effective FRS demonstrated the ability of PBN to inhibit signal transduction processes such as suppression of proinflammatory cytokines, genes, and mediators associated with enhanced neuroinflammatory processes (Figure 1). ${ }^{12}$ The neuroprotective activity of the nitrone pharmacophore depends in great part on the connectivity and the nature of substituents on the nitrone group. In this sense, the chemical and pharmacological aspects of different heteroarylnitrones have been reviewed, ${ }^{13}$ describing 
<smiles>[R]c1ccc(C=[N+]([R])[O-])o1</smiles>

I, $\mathrm{R}_{1}=-\mathrm{C}\left(\mathrm{CH}_{3}\right)_{3} \mathrm{R}_{2}=-\mathrm{SO}_{3}{ }^{-\mathrm{Na}^{+}}$

II, $\mathrm{R}_{1}=-\mathrm{C}_{6} \mathrm{H}_{11} \mathrm{R}_{2}=-\mathrm{SO}_{3}{ }^{-\mathrm{Na}}{ }^{+}$

III, $\mathrm{R}_{1}=-\mathrm{C}\left(\mathrm{CH}_{3}\right)_{3} \mathrm{R}_{2}=-\mathrm{SO}_{2} \mathrm{~N}\left(\mathrm{CH}_{3}\right)_{2}$

Furyl Nitrones<smiles>CC(C)(C)[N+]([O-])=Cc1c[nH]c(-c2ccccc2)n1</smiles><smiles>CC(C)(C)[N+]([O-])=Cc1nc(-c2ccccc2)c[nH]1</smiles>

Imidazolyl Nitrones

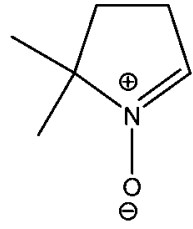

VI, DMPO

Figure 2. Heteroarylnitrones with neuroprotective and spin trapping properties.

Scheme 1. Heteroarylnitrones Designed as Potential Drugs for Neurodegenerative Diseases<smiles>c1csnn1</smiles>

$1,2,3$ and 1,2,4-thiadiazole

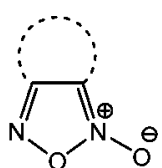

Furoxan and Benzofuroxan

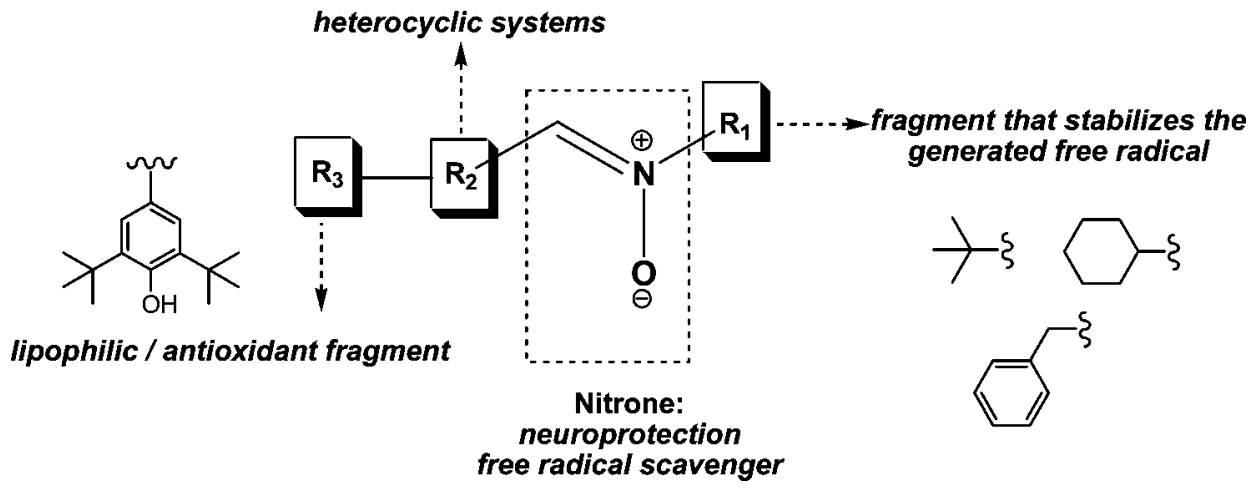

some patented nitrone containing furans (I-III, Figure 2) with good activity against the neuronal cell damage induced by $\beta$-amyloid. ${ }^{14}$ On the other hand, imidazolylnitrones (IV and $\mathbf{V}$, Figure 2) has been developed and biologically evaluated, showing in vivo neuroprotective properties. ${ }^{15}$ Additionally several nitrones has been widely used as spin trap for the specific detection of transient radicals (e.g., ${ }^{\circ} \mathrm{OH}, \mathrm{O}_{2}{ }^{--}, \mathrm{ROO}^{\circ}$ ) or relatively stable radicals (e.g., NO) that are undetectable under normal conditions, ${ }^{16}$ in the electron spin resonance (ESR) spectroscopy. With this aim two nitrones have been commonly used in the spin trapping technique: the linear nitrone PBN (Figure 1) and the cyclic nitrone DMPO (5,5-dimethyl-1pyrroline $N$-oxide VI, Figure 2).

On the basis of that, herein we describe the design and synthesis of new heteroarylnitrones combining, in their structures, fragments able to show neuroprotection properties, such as nitrone moiety, antioxidant fragments, and heterocyclic groups able to stabilize the generated free radical (Scheme 1). In order to assess the protective effects of heteroarylnitrones, the effects of $\mathrm{H}_{2} \mathrm{O}_{2}$-injured in neuronal cells ( $\mathrm{SH}-\mathrm{SY} 5 \mathrm{Y}$ ) and in vitro unspecific cytotoxicity against J774-mouse macrophages were evaluated. Additionally, the antioxidant activities and the spin trapping properties have been investigated by evaluating the direct reaction with oxygen-, carbon-, and sulfur-centered free radicals by antioxidant assays and ESR spectroscopy.

\section{Results and Discussion}

Chemistry. Four different families of heteroarylnitrones were selected to study the influence on the biological activity: 1,2,3- thiadiazole, 1,2,4-thiadiazole, 1,2,5-oxadiazole $\mathrm{N}$-oxide, and benzo[1,2-c]1,2,5-oxadiazole $N$-oxide derivatives. ${ }^{17,18}$ The nitrones syntheses were planned through the condensation between the corresponding heteroaromatic aldehyde and $\mathrm{N}$-substituted hydroxylamine, ${ }^{19}$ our first goal being the preparation of the corresponding aldehyde derivatives. For the synthesis of 3- and 5-formyl-1,2,4-thiadiazole aldehydes, 6 and 9, respectively, the synthetic routes shown in Scheme 2a were employed. First, the reaction of benzothioamide with $N, N$-dimethylalkanamide dimethyl acetals produced the corresponding $N^{\prime}$-(thioaroyl)- $N, N$ dimethylamidines $\mathbf{1}$ and $\mathbf{2}$ in excellent yield. ${ }^{20}$ These intermediates were converted by amination-cyclization into the $1,2,4$ thiadiazole $\mathbf{3}$ and $\mathbf{4}$. The 3-formyl-1,2,4-thiadiazole $\mathbf{6}$ was obtained through bromination-oxidation of thiadiazole 4 . Attempts to obtain aldehyde $\mathbf{6}$ using formylation reaction between 5-phenyl-1,2,4-thiadiazole 3 and $n$-BuLi in DMF were unsuccessful. In these conditions, the ring-opening product, $\mathbf{5}$, was mainly generated. Oxidation of the methyl substituent in compound $\mathbf{4}$ using selenium dioxide was also explored in the preparation of aldehyde $\mathbf{6}$; however, no reaction was observed. Second, nitrile sulfide, obtained in situ through thermolysis of the 1,3,4-oxathiazol-2-one 7 (Scheme 2a), was treated with ethyl cyanoformate, yielding ester $\mathbf{8}$ via a 1,3-dipolar cycloaddition process. $^{21}$ Subsequently, the desired aldehyde 9 was prepared by reduction of $\mathbf{8}$ with DIBAL-H and subsequent oxidation with $\mathrm{MnO}_{2}$. In order to know the 1,2,4-thiadiazole-substituents stereoelectronic/antioxidant effects (Scheme 1), different 3-aryl substitutions were studied (Scheme 2b). Consequently, aldehydes 18, 20, and $\mathbf{2 1}$ were prepared following the same synthetic 
Scheme 2. Synthesis of Formyl-Heterocycle Derivatives ${ }^{a}$

a)

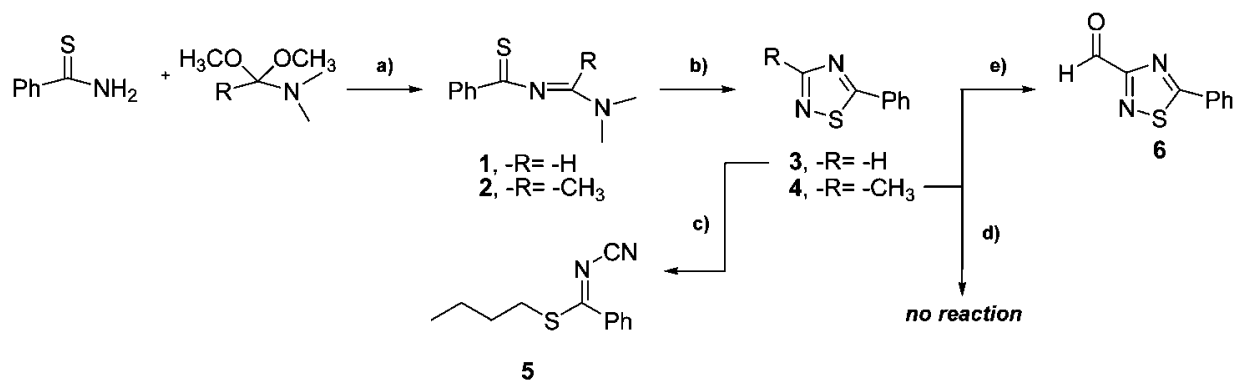<smiles>CCOC(=O)c1ccccc1</smiles>

b)

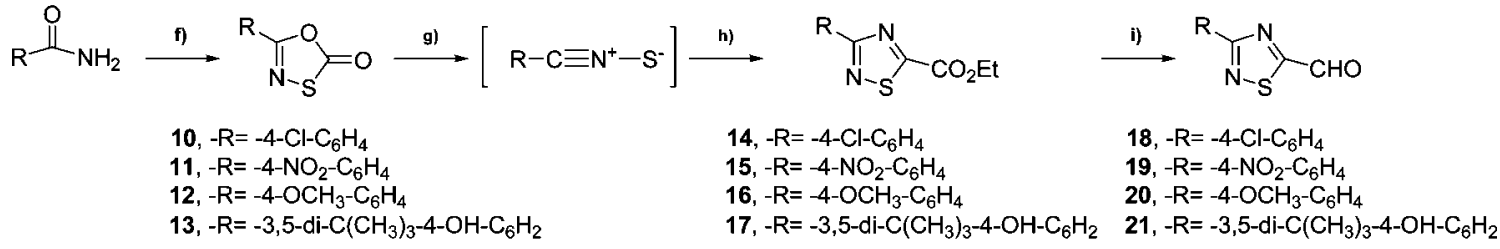

c)

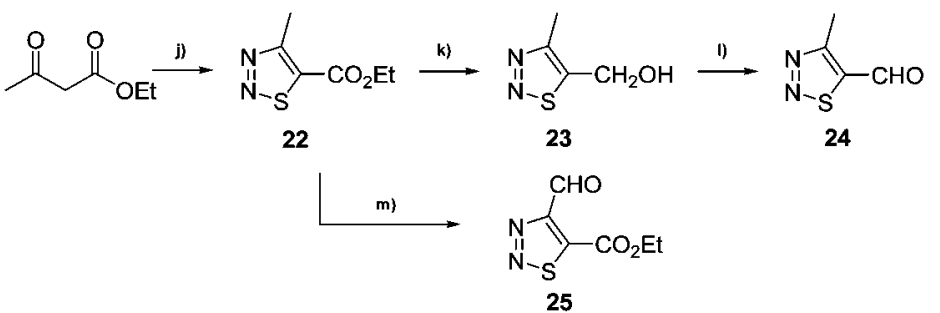

d)

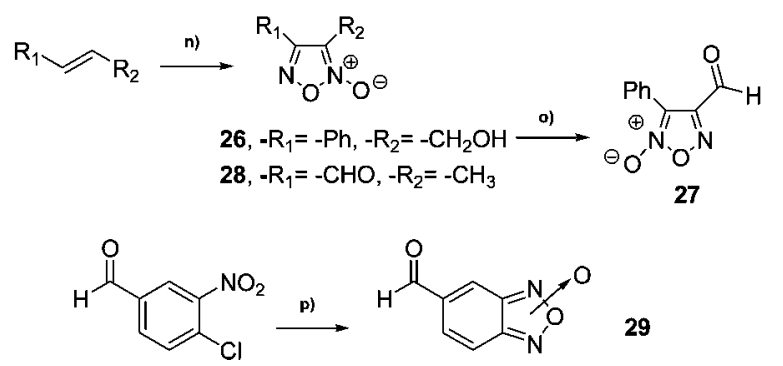

${ }^{a}$ Reagents and conditions: (a) room temp; (b) $\mathrm{HSA}, \mathrm{Py}, \mathrm{EtOH}$, room temp; (c) $n$ - $\mathrm{BuLi}$, THF, $-78^{\circ} \mathrm{C}$, then $\mathrm{DMF}, 0{ }^{\circ} \mathrm{C}$; (d) $\mathrm{SeO}_{2}, \mathrm{dioxane}^{\circ} \mathrm{ClCH}_{2} \mathrm{CH}_{2} \mathrm{Cl}$, reflux; (e) NBS, PDBO, $\mathrm{CCl}_{4}$, reflux, then DSMO, $105^{\circ} \mathrm{C}$; (f) $\mathrm{Cl}(\mathrm{C}=\mathrm{O}) \mathrm{SCl}$, toluene, reflux; (g) decaline, $140-160{ }^{\circ} \mathrm{C}$; (h) EtO $\mathrm{Et}_{2} \mathrm{C}-\mathrm{CN}$; (i) (1) $\mathrm{DIBAL}-\mathrm{H}$, THF, $0{ }^{\circ} \mathrm{C}$; (2) $\mathrm{MnO}_{2}, \mathrm{CHCl}_{3}$, reflux; (j) (1) $\mathrm{H}_{2} \mathrm{NNHCO}_{2} \mathrm{Met}$, $p$ - TsOH, toluene, reflux; (2) $\mathrm{SOCl}_{2}, 60{ }^{\circ} \mathrm{C}$; (k) $\mathrm{NaBH}_{4}, \mathrm{EtOH}$, room temp; (l) $\mathrm{MnO}_{2}$, $\mathrm{CHCl}_{3}$, reflux; (m) NBS, PDBO, $\mathrm{CCl}_{4}$, reflux, then DSMO, $120{ }^{\circ} \mathrm{C}$; (n) $\mathrm{NaNO}_{2}, \mathrm{AcOH}, 0{ }^{\circ} \mathrm{C}$; (o) $\mathrm{MnO}_{2}, \mathrm{CHCl}_{3}$, room temp; (p) (1) NaN $3, \mathrm{DMSO}, 60-70{ }^{\circ} \mathrm{C}$; (2) DMSO, $90-100{ }^{\circ} \mathrm{C}$.

route for aldehyde 9 preparation. Attempts to obtain the desired 4- $\mathrm{NO}_{2}$ analogue $\mathbf{1 9}$ were unsuccessful because of the low stability of ester $\mathbf{1 5}$ in the reduction conditions (i) (Scheme 2b). The 1,2,3-thiadiazole carbonylic reagents were prepared from ethyl acetoacetate following a condensation with methyl carbazate, forming the corresponding acylhydrazone, and subsequent cyclization via Hurd-Mori reaction in the presence of thionyl chloride (Scheme 2c). ${ }^{22}$ Then thiadiazole 22 was transformed into the key aldehydes $\mathbf{2 4}$ and $\mathbf{2 5}$ by reduction/ oxidation for the first case and by benzylic-like bromination/ oxidation for the second. Finally, the synthetic procedures for furoxan and benzofuroxan systems included, for the first heterocycle, addition to alkenes followed by intramolecular cyclization and thermointramolecular cyclization for the second one (Scheme 2d). Consequently, the reaction of cinnamyl alcohol or crotonaldehyde with $\mathrm{NaNO}_{2}$ in $\mathrm{AcOH}$ produced the furoxan derivatives 26 and 28, respectively. ${ }^{23}$ Alcohol 26 was converted into the aldehyde 27 by oxidation with $\mathrm{MnO}_{2}{ }^{23}$ The formylbenzofuroxan $\mathbf{2 9}$ was obtained from 4-chloro-3-nitrobenzaldehyde in a one-pot process via nucleophilic substitution with the azide anion and subsequent cyclization by pyrolysis of the corresponding $o$-nitrophenylazide intermediate. ${ }^{24}$ The desired nitrones, 30-41, were obtained in good yield for reaction between the corresponding aldehydes 6, 9, 18, 20, 21, 24, 25, 27-29 and $\mathrm{N}$-substituted hydroxylamine hydrochloride in the presence of $\mathrm{NaHCO}_{3}$ (Scheme 3). Taking into account that the nitrone stability, as well as the stability of the corresponding spin-adduct (nitroxyl free radical), is highly influenced by the $N$-alkyl substituent, ${ }^{13}$ we developed derivatives $\mathbf{3 1 - 3 3}$ by 
Scheme 3. Synthesis and Structure of New Heteroarylnitrones ${ }^{a}$

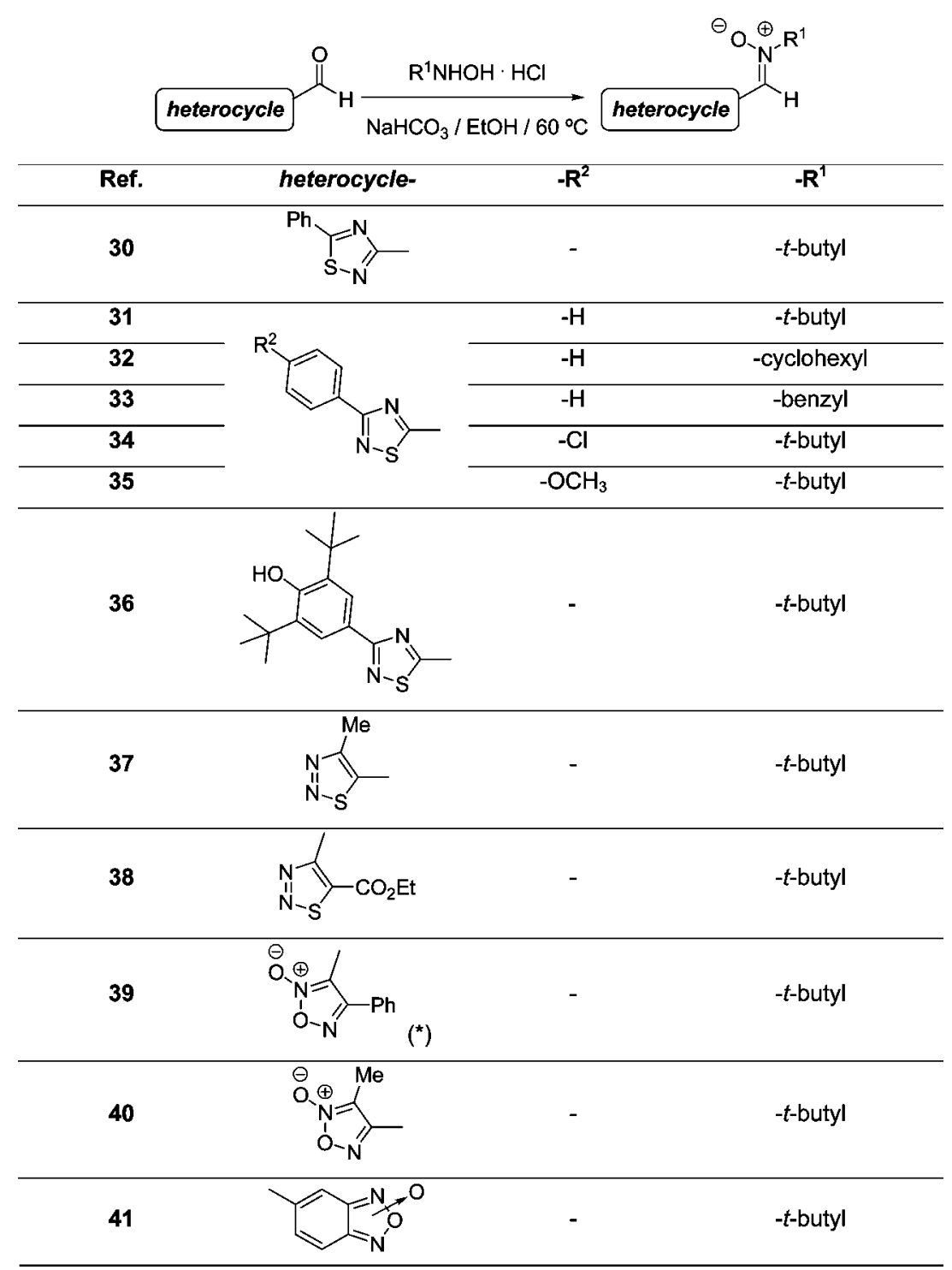

${ }^{a}$ Asterisk $(*)$ indicates at room temperature.

varying $\mathrm{R}^{1}$ (Scheme 3 ) in order to evaluate the effect of this modulation in the bioactivity studies.

All the structures of the desired nitrones, 30-41, were established by NMR $\left({ }^{1} \mathrm{H},{ }^{13} \mathrm{C}, \mathrm{HMQC}\right.$, and HMBC experiments), IR, and MS. The purity was established by TLC and microanalysis. The stereochemistry around the olefinic carbonnitrogen bond of the nitrone function was established using NOE-diff experiments, and they are Z-isomers in all the cases.

Biology. Neuroprotective Activity. The neuroprotective activity of the new developed heteroarylnitrones, 30-41, was studied using a human neuronal-like cellular system (SH-SY5Y cells) exposed to $\mathrm{H}_{2} \mathrm{O}_{2}$ as oxidative damaging agent. ${ }^{25}$ First, SH-SY5Y cytotoxicity of the developed heteroarylnitrones and $\mathrm{PBN}$ was evaluated in vitro in the range $0.05-10 \mu \mathrm{M}$ for $24 \mathrm{~h}$. The cell viability was determined by measuring the activity of lactate dehydrogenase (LDH) released into the culture medium and expressed as the difference between nitrones-treated and untreated cells. All the nitrones displayed no cytotoxicity for neuronal cells, $100 \%$ of survival, at assayed neuroprotective doses $(10 \mu \mathrm{M})$. Second, each one of the heteroarylnitrones, at $10 \mu \mathrm{M}$ doses, was administered to the cells $1 \mathrm{~h}$ before the incubation with $\mathrm{H}_{2} \mathrm{O}_{2}$. The cell viability was determined by measuring the activity of LDH released and expressed as the difference between nitrones-treated and untreated cells. The basal percentage of viable neurons after treatment with $100 \mu \mathrm{M}$ $\mathrm{H}_{2} \mathrm{O}_{2}$ was $45 \%$, and $N$-acetylcysteine (NAC) was used as positive test at $5 \mathrm{mM}$ (Figure 3 ). The values summarized in Table 1 show that the 1,2,4-thiadiazolylnitrones 30-36 and the furoxanylnitrone $\mathbf{4 0}$ protect similarly to or slightly higher against the cellular damage than the parent nitrone PBN, with values between $33 \%$ and $46 \%$. Interestingly, the treatment of SH-SY5Y cells with the 1,2,4-thiadiazolylnitrone 36 at $1 \mu \mathrm{M}$ significantly protects against $\mathrm{H}_{2} \mathrm{O}_{2}$ induced neurotoxicity, with a value of 20\% (Figure 3). Furthermore, the benzofuroxanylnitrone 41 showed lower capacity to protect neuroblastoma human cells from death induced by oxidative stress than PBN, while the 1,2,3-thiadiazolylnitrones ( $\mathbf{3 7}$ and $\mathbf{3 8}$ ) and furoxanylnitrone $\mathbf{3 9}$ did not show neuroprotective effects. These results revealed the consequence of the connectivity and the nature of the nitronepharmacophore substituents in the neuroprotective activity. The 1,2,4-thiadiazolylnitrones $\mathbf{3 1}, \mathbf{3 2}$, and $\mathbf{3 3}$, substituted in the nitrogen atom of the nitrone by a tert-butyl, cyclohexyl, and benzyl group, respectively, exhibited differential activity, indicating some $\mathrm{N}$-alkyl moieties dependence. 


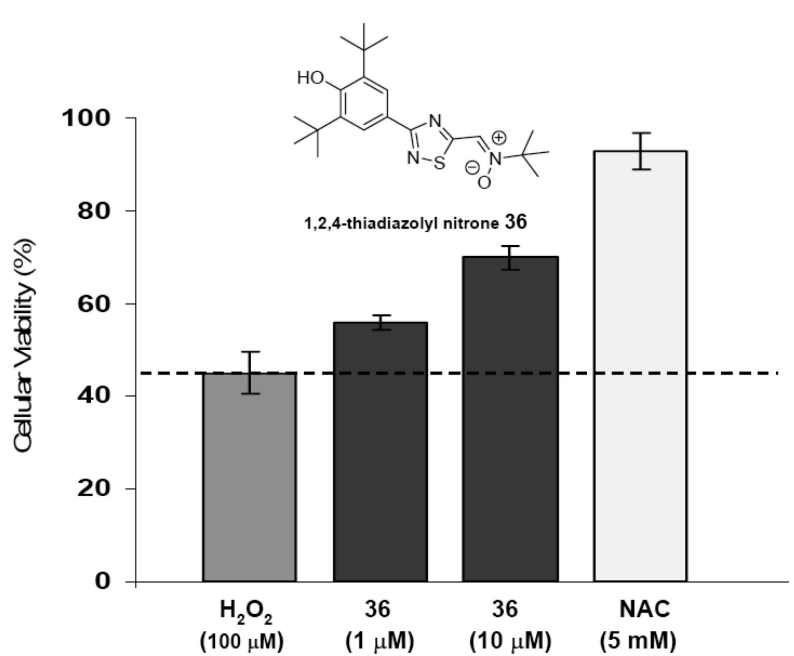

Figure 3. Cellular viability in different experimental conditions: $\mathrm{H}_{2} \mathrm{O}_{2}$ $(100 \mu \mathrm{M})$, nitrone 36 (at 10 and $1 \mu \mathrm{M})$, and NAC (5 mM) used as positive test. Viability was determined through LDH activity after $24 \mathrm{~h}$ of incubation (mean $\pm \mathrm{SD}$ values from three independent experiments).

Table 1. Effect of Heteroarylnitrones on Cell viability in SH-SY5Y Cells Preincubated with $\mathrm{H}_{2} \mathrm{O}_{2}(100 \mu \mathrm{M})$ and Heteroarylnitrones Cytotoxicities (J774 Mouse Macrophages)

$\begin{array}{llcc}\text { ref } & \begin{array}{c}\text { difference in cell } \\ \text { viability }{ }^{a-c}\end{array} & \text { \% neuroprotection } & \\ \text { PBN } d & \mathrm{~J}^{-c} 74 \mathrm{IC}_{50}(\mu \mathrm{M})^{e} \\ \mathbf{3 0} & 20.6 \pm 0.2 & 37 & >400 \\ \mathbf{3 1} & 20.0 \pm 1.9 & 36 & >400 \\ \mathbf{3 2} & 20.7 \pm 9.4 & 38 & >400 \\ \mathbf{3 3} & 23.6 \pm 10.7 & 43 & 100 \\ \mathbf{3 4} & 18.1 \pm 3.0 & 33 & 240 \\ \mathbf{3 5} & 25.0 \pm 5.2 & 34 & 200 \\ \mathbf{3 6} & 25.2 \pm 5.6 & 46 & >400 \\ \mathbf{3 7} & 0 & 46 & >400 \\ \mathbf{3 8} & 0 & & >400 \\ \mathbf{3 9} & 0 & & 100 \\ \mathbf{4 0} & 23.0 \pm 2.4 & 42 & >400 \\ \mathbf{4 1} & 13.4 \pm 6.0 & 24 & 150\end{array}$

${ }^{a}$ The cell viability was measured with $\mathrm{LDH}$ activity being $100 \%$ the basal value. The basal value was obtained from the cells that did not receive any treatment. Difference of cell viability was determined by the difference between $\mathrm{LDH}$ activity in nitrones $-\mathrm{H}_{2} \mathrm{O}_{2}$-treated cells and $\mathrm{LDH}$ activity in $\mathrm{H}_{2} \mathrm{O}_{2}$-treated cells and normalized to $100 \%$. ${ }^{b}$ Data are expressed as the mean \pm SD $(p<0.001)$. Experiments were done in triplicate. ${ }^{c}$ Doses of heteroarylnitrones are $10 \mu \mathrm{M} .{ }^{d}$ Basal percentage of viable neurons after treatment with $100 \mu \mathrm{M} \mathrm{H}_{2} \mathrm{O}_{2}$ is $45 \%$. The percentages of neuroprotection are determined from the basal values. ${ }^{e} \mathrm{IC}_{50}$ : concentration that produces $50 \%$ inhibitory effect. The results are the mean values of two different experiments with SD values less than $10 \%$ in all cases.

Mammal Cytotoxicity. Unspecific mammalian cytotoxicity of the developed heteroarylnitrones was evaluated in vitro in the range $50-400 \mu \mathrm{M}$, using $\mathrm{J} 774$ mouse macrophages as the cellular model (Table 1). ${ }^{26}$ In the study PBN was included as a neuroprotective reference compound. The developed heteroarylnitrones displayed no cytotoxicity for mammalian cells at its neuroprotective doses $(10 \mu \mathrm{M})$. Furthermore, the most active heteroarylnitrones, 35, 36 and 40, show low mammalian cytotoxicity in the assayed in vitro model, these compounds being as cytotoxic as the parent compound PBN. Moreover, the $\mathrm{IC}_{50}$ values summarized in Table 1 show that the 1,2,4thiadiazolyl, 32-34, furoxanyl, 39, and benzofuroxanylnitrones, 41, are a little more toxic against this cellular system than the parent compound PBN.

Blood-Brain Barrier Permeation Studies. For the 1,2,4thiadiazolylnitrones $\mathbf{3 5}$ and $\mathbf{3 6}$, with the best neuroprotective<smiles>COc1ccc(-c2nsc(C=N[N+](=O)C(C)(C)C)n2)cc1</smiles><smiles>CC(C)(C)C(=O)O/N=C/c1nc(-c2cc(C(C)(C)C)c(O)c(C(C)(C)C)c2)ns1</smiles>

$P_{e}=12.5 \times 10^{-6} \mathrm{~cm} \mathrm{~s}^{-1}($ CNS +$)$

$P_{e}=4.5 \times 10^{-6} \mathrm{~cm} \mathrm{~s}^{-1}$ (CNS + )

Figure 4. Prediction of the brain penetration using PAMPA-BBB assay by 1,2,4-thiadiazolylnitrones $\mathbf{3 5}$ and $\mathbf{3 6}$ (CNS +: compounds able to cross the $\mathrm{BBB}$ ).

Table 2. Free-Radical Scavenger/Antioxidant Activity of Heteroarylnitrone Derivatives Using $\mathrm{ORAC}_{\mathrm{FL}}$ Method and DPPH Captured

$\begin{array}{lcc}\text { ref } & \text { ORAC (PBN equiv) } & \text { RP of DPPH }(\%)^{b} \\ \text { PBN } & 1.0 & 0\left(20^{c}\right) \\ \mathbf{3 0} & 2.0 \pm 0.1 & 41 \pm 3 \\ \mathbf{3 1} & 5.5 \pm 0.1 & 0 \\ \mathbf{3 2} & 4.6 \pm 0.2 & 11 \pm 3 \\ \mathbf{3 3} & 3.5 \pm 0.3 & 0 \\ \mathbf{3 4} & 1.5 \pm 0.2 & 0 \\ \mathbf{3 5} & 7.0 \pm 0.4 & 10 \pm 4 \\ \mathbf{3 6} & 6.0 \pm 0.2 & 40 \pm 3 \\ \mathbf{3 7} & 2.5 \pm 0.1 & 0 \\ \mathbf{3 8} & 3.0 \pm 0.1 & 0 \\ \mathbf{3 9} & 6.0 \pm 0.2 & 0 \\ \mathbf{4 0} & 2.5 \pm 0.1 & 8 \pm 1 \\ \mathbf{4 1} & 16.5 \pm 0.4 & 17 \pm 5\end{array}$

${ }^{a}$ Data are expressed as $\mu \mathrm{mol}$ of PBN equiv/ $\mu \mathrm{mol}$ of tested heteroarylnitrones and are the mean $(n=3) \pm \mathrm{SD} .{ }^{b}$ All heteroarylnitrones were assayed at $0.1 \mathrm{mM} .{ }^{c}$ Evaluated at $10 \mathrm{mM}$.

profile and the lowest mammalian cytotoxicity (Table 1), the capacity to cross the blood-brain barrier (BBB) by means of a parallel artificial membrane permeation assay for BBB (PAMPABBB) using a lipid extract of porcine brain was determined. The assay validation was made by comparing experimental permeabilities of 20 commercial drugs to reported values. ${ }^{27}$ From this experiment and taking into account the limit established by Di et al. for BBB permeation, compounds with permeability $\left(P_{\mathrm{e}}\right)$ above $4.4 \times 10^{-6} \mathrm{~cm} \mathrm{~s}^{-1}$ could cross the BBB (Figure 4). ${ }^{28}$

Free-Radical Scavenger Properties Antioxidant Activity. The antioxidant activity of the newly developed heteroarylnitrones was determined using two in vitro assays, the oxygen radical absorbance capacity (ORAC) and the measurement of reduction percentage (RP) of the stable diphenylpicrylhydrazyl free radical (DPPH). ORAC assay ${ }^{29}$ measures peroxyl free radical scavenger compounds capability and using fluorescein (FL) as the fluorescent probe. The peroxidation of FL yields nonfluorescent products at $520 \mathrm{~nm}$, so the remaining fluorescence of FL in the presence of the free radical scavenger compound is a measure of the antioxidant activity of the test compound. In this assay the results were expressed in reference to PBN, as PBN equiv ( $\mu$ moles of PBN equivalents per $\mu$ moles of tested compound) (Table 2). On the other hand, the RP of DPPH is based on the reaction between the deep-violet stable free radical (characterized by an absorption band in ethanol solution centered at 520 $\mathrm{nm}$ ) and the studied free radical scavenger measuring the absorbance of nitrone-treated and untreated DPPH solutions (Table 2) ${ }^{30}$ The peroxyl free radical scavenger property of our nitrones, according to ORAC assay, was better than that of PBN, being 1.5-16.5 higher than PBN value. The benzofuroxanylnitrone 41 showed the highest $\mathrm{ORAC}_{\mathrm{FL}}$ value (16.5 PBN equiv), whereas the 1,2,4-thiadiazolylnitrone $\mathbf{3 4}$ showed the lowest $\mathrm{ORAC}_{\mathrm{FL}}$ value (1.5 PBN equiv). Similar results of antioxidant 


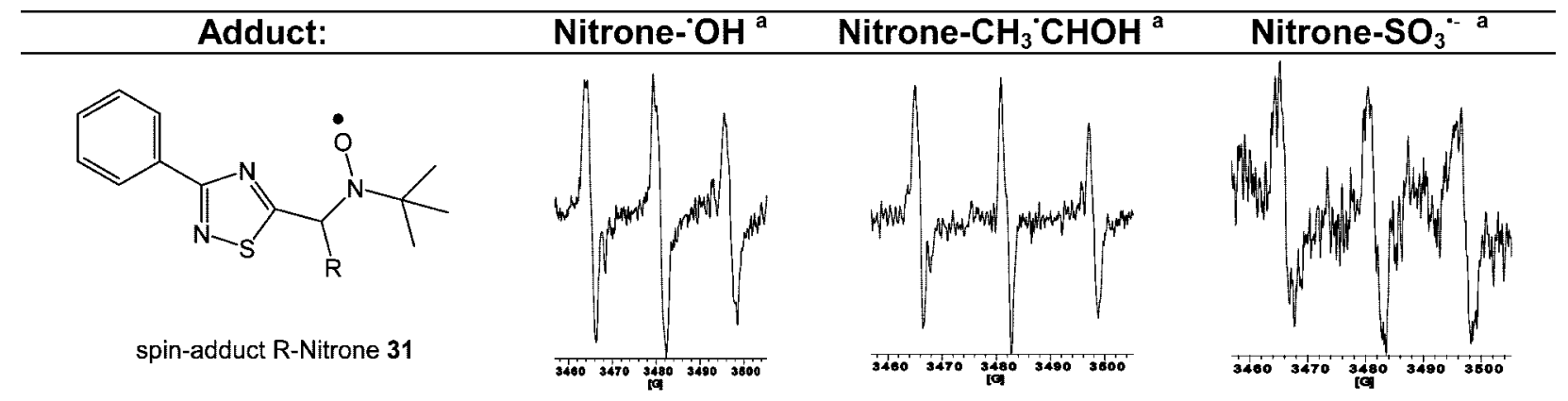<smiles>[R]C(c1nnsc1C(=O)OC)N([O])C(C)(C)C</smiles>

spin-adduct R-Nitrone $\mathbf{3 8}$
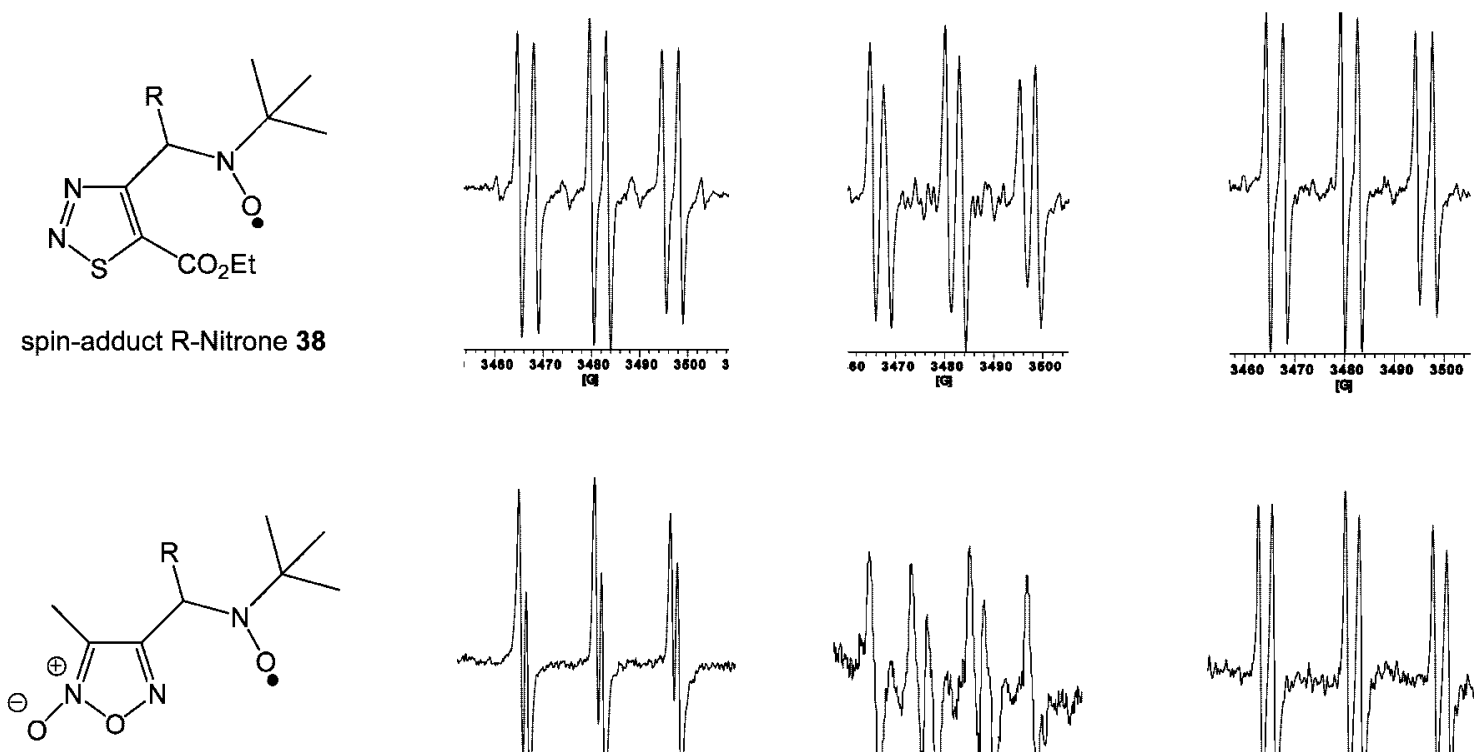

spin-adduct R-Nitrone $\mathbf{4 0}$
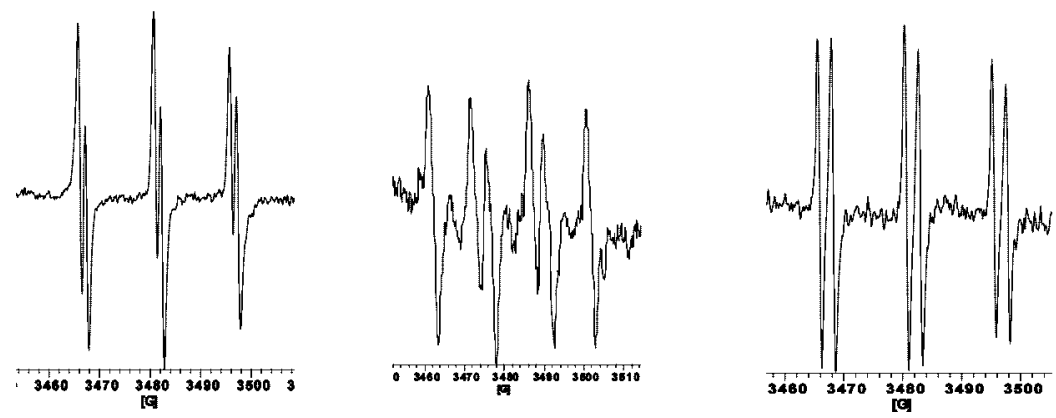

Figure 5. ESR spectra obtained in the trapping of ${ }^{\circ} \mathrm{OH}, \mathrm{CH}_{3}{ }^{\circ} \mathrm{CH}_{2} \mathrm{OH}$, and $\mathrm{SO}_{3}{ }^{\circ}$ free radicals with nitrones 31, 38, and 40. Superscript "a" in the heading entries indicates that ${ }^{\circ} \mathrm{OH}, \mathrm{CH}_{3}{ }^{\circ} \mathrm{CHOH}$, and $\mathrm{SO}_{3}{ }^{\circ}$ free radicals are generated by Fenton's reaction.

activity were obtained through DPPH assay. The heteroarylnitrones were tested at $0.1 \mathrm{mM}$, being more potent antioxidants than PBN, which at $10 \mathrm{mM}$ possess $20 \%$ of DPPH reduction. In this sense, the 1,2,4-thiadiazolylnitrones $\mathbf{3 0}$ and $\mathbf{3 6}$ showed the highest antioxidant values, 41 and 40 DPPH RP, respectively.

Electron Spin Resonance Measurements. Initially the ${ }^{\circ} \mathrm{OH}-$ spin trapping ability of the developed heteroarylnitrones was investigated using ESR spectroscopy. The ${ }^{\circ} \mathrm{OH}$ free radical was generated in situ from a Fenton reaction system. All the assayed heteroarylnitrones, except the thiadiazolylnitrones $\mathbf{3 2}$ and $\mathbf{3 3}$ and furoxanylnitrone 39, gave strong ESR signals (Figure 5), and the hyperfine splitting (HFS) constants for the different spin adducts are reported in Table 3. These data indicate that in general our heteroarylnitrones generate stable spin adducts with ${ }^{\circ} \mathrm{OH}$, like previously reported imidazolylnitrones. ${ }^{31}$ The absence of signal in the cases of nitrones $\mathbf{3 2}$ and $\mathbf{3 3}$ indicated that the cyclohexyl and benzyl groups affect the stability of the spin adduct generated under the studied conditions.

In order to study the capability of the developed nitrones as spin trapping against other free radical species, we selected one nitrone from each proposed family. Consequently, the 1,2,4thiadiazolylnitrone 31, the 1,2,3-thiadiazolylnitrone $\mathbf{3 8}$, and the furoxanylnitrone 40 were studied as both ethanol and sulfite free radical spin trappings. The ESR signals obtained for these heteroarylnitrones are given in Figure 5. The ESR signals for the free radical adducts with nitrones $\mathbf{3 1}, \mathbf{3 8}$, and $\mathbf{4 0}$ indicated
Table 3. HFS Constants for the Heteroarylnitrone- $-^{-} \mathrm{OH}$ Spin Adduct

$\begin{array}{ccc}\begin{array}{c}\text { nitrone }-{ }^{-} \mathrm{OH}^{a, b} \\ \text { spin adduct, ref }\end{array} & a_{\mathrm{N}}(\mathrm{G})^{c} & a_{\mathrm{H} \beta}(\mathrm{G})^{c} \\ \mathbf{3 0} & 14.8 & 2.4 \\ \mathbf{3 1} & 15.7 & 0.9 \\ \mathbf{3 2} & \mathrm{ns}^{d} & \mathrm{~ns}^{d} \\ \mathbf{3 3} & 15.3 & \mathrm{~ns}^{d} \\ \mathbf{3 4} & 15.7 & 0.6 \\ \mathbf{3 5} & 14.0 & 0.7 \\ \mathbf{3 6} & 14.5 & 2.6 \\ \mathbf{3 7} & 15.5 & 2.6 \\ \mathbf{3 8} & \mathrm{ns}^{d} & 4.0 \\ \mathbf{3 9} & 15.8 & \mathrm{~ns}^{d} \\ \mathbf{4 0} & 14.1 & 2.1 \\ \mathbf{4 1} & & 2.2\end{array}$

$a \cdot \mathrm{OH}$ was generated from a standard Fenton system: $\mathrm{Fe}\left(\mathrm{NH}_{4}\right)_{2}$ $\left(\mathrm{SO}_{4}\right)_{2} \cdot 6 \mathrm{H}_{2} \mathrm{O}(0.5 \mathrm{mM})$ was added to a solution of nitrone $(50 \mathrm{mM})$ and $\mathrm{H}_{2} \mathrm{O}_{2}(0.5 \mathrm{mM})$ in phosphate buffer $(0.1 \mathrm{M}) .{ }^{b}$ The ESR spectrum of the spin adduct was recorded $30 \mathrm{~s}$ after addition of $\mathrm{FeSO}_{4} \cdot{ }^{c}$ G: gauss. ${ }^{d}$ ns: no signals in the assayed conditions.

that these nitrones are also very efficient to trap and stabilize both carbon- and sulfur-centered free radicals, $\mathrm{CH}_{3}{ }^{\circ} \mathrm{CHOH}$ and $\mathrm{SO}_{3}{ }^{--}$, respectively. These results suggest that our nitrones have great capacity to scavenge free radicals and potential use to prevent or reduce the damage caused by radicals in several degenerative disorders. However, because nitrone $\mathbf{3 8}$ is very efficient in spin trapping (i.e., ${ }^{\circ} \mathrm{OH}, \mathrm{CH}_{3}{ }^{\circ} \mathrm{CHOH}, \mathrm{SO}_{3}{ }^{-}$, Figure 5), it does not have neuroprotective effects in the neuroblastoma 
human SH-SY5Y system (Table 1), showing that the neuroprotective activity might not exclusively reside in its capacity to scavenge free radicals. These results are similar to those recently reported for other heteroarylnitrones. ${ }^{32}$

\section{Conclusion}

New series of thiadiazolyl and furoxanylnitrones have been synthesized and biologically evaluated as potential neuroprotective agents for the treatment of neurodegenerative disorders. The designed heteroarylnitrones were efficiently obtained through the condensation between heteroaromatic aldehydes and $\mathrm{N}$-monosubstituted hydroxylamines with good to excellent yields and chromatographically isolated as pure $Z$-isomers. They show excellent free radical scavenger capacity and good neuroprotective effects without cellular toxicity. The ESR spectroscopy demonstrated the ability of these heteroarylnitrones to directly scavenge different free radicals (i.e., ${ }^{\circ} \mathrm{OH}, \mathrm{CH}_{3}{ }^{\circ} \mathrm{CHOH}, \mathrm{SO}_{3}{ }^{-}$). Taking into account all the results, the designed heteroarylnitrones have demonstrated a therapeutic potential as neuroprotective agents in preventing the death of cells exposed to enhanced oxidative stress and damage. Further structural optimization, QSAR, and in vivo neuroprotective property studies are currently underway.

\section{Experimental Section}

Compounds $\mathbf{3}, \mathbf{4},{ }^{20} \mathbf{8},{ }^{21} \mathbf{1 4}-\mathbf{1 7},{ }^{33-36}$ and $\mathbf{2 6}-\mathbf{2 9}^{23}$ were prepared according to literature procedures. Melting points were determined with an electrothermal melting point apparatus (Electrothermal 9100) and are uncorrected. Proton and carbon NMR spectra were recorded on a Bruker DPX-400 spectrometer. The chemical shifts values are expressed in ppm relative to tetramethylsilane as internal standard. Mass spectra were determined in a MSD 5973 HewlettPackard or LC/MSD series 100 Hewlett-Packard spectrometer using electronic impact (EI) or electrospray ionization (ESI), respectively. Microanalyses were performed in a Fisons EA 1108 CHNS-O equipment and were within $\pm 0.4 \%$ of the calculated compositions. Column chromatography was carried out using Merck silica gel (60-230 mesh). Most chemicals and solvents were analytical grade and used without further purification. All the reactions were carried out in a nitrogen atmosphere. The typical workup included washing with brine and drying the organic layer with sodium sulfate before concentration.

3-Formyl-5-phenyl-1,2,4-thiadiazole (6). A mixture of $\mathbf{4}^{20}(0.4$ g, $2.3 \mathrm{mmol}), \mathrm{N}$-bromosuccinimide $(0.45 \mathrm{~g}, 2.5 \mathrm{mmol})$, and dibenzoyl peroxide $(0.08 \mathrm{~g}, 0.34 \mathrm{mmol})$ in dry $\mathrm{CCl}_{4}(8.0 \mathrm{~mL})$ was heated at reflux for $16 \mathrm{~h}$. Then the mixture was allowed to cool to room temperature, the succinimide was collected and washed with $\mathrm{CCl}_{4}(10.0 \mathrm{~mL})$, and the organic layer was evaporated in vacuo. 3-Bromomethyl-5-phenyl-1,2,4-thiadiazole was obtained as an oil ( $\sim 40 \%$ by ${ }^{1} \mathrm{H}$ NMR signals) and was used in the next reaction without further purification. ${ }^{1} \mathrm{H} \mathrm{NMR}\left(\mathrm{CDCl}_{3}, 400 \mathrm{MHz}\right) \delta: 4.69$ $(\mathrm{s}, 2 \mathrm{H}), 7.45-7.55(\mathrm{~m}, 3 \mathrm{H}), 7.90-8.00(\mathrm{~m}, 2 \mathrm{H})$. The crude of the bromination process in DMSO $(6.0 \mathrm{~mL})$ was stirred and warmed at $105^{\circ} \mathrm{C}$ during $1.5 \mathrm{~h}$. Subsequently, the mixture was poured into saturated sodium chloride solution $(30.0 \mathrm{~mL})$ and extracted with EtOAc $(3 \times 20.0 \mathrm{~mL})$. After the workup of the combined organic layers, the residue was purified by column chromatography $\left(\mathrm{SiO}_{2}\right.$, petroleum ether/EtOAc (9:1)), yielding derivative $\mathbf{6}$ as a yellow oil (130 mg, 30\% two steps). ${ }^{1} \mathrm{H}$ NMR $\left(\mathrm{CDCl}_{3}\right) \delta: 7.45-7.65$ (m, $3 \mathrm{H}), 7.90-8.10(\mathrm{~m}, 2 \mathrm{H}), 10.30(\mathrm{~s}, 1 \mathrm{H})$. EI-MS, $\mathrm{m} / \mathrm{z}$ (abundance, \%): $190\left(\mathrm{M}^{+\bullet}, 27\right), 135$ (100), 103 (15).

General Procedure for the Synthesis of 3-Aryl-5-formyl-1,2,4thiadiazole Derivatives (9 and 18-21). A solution of the corresponding ester ${ }^{20,33-36}$ (1 equiv) in THF (4 mL/mmol) as solvent was cooled at $0{ }^{\circ} \mathrm{C}$. Then a solution of DIBAL-H $(1 \mathrm{M}$ in hexane, $2-3$ equiv) was added slowly and the final mixture was stirred during $3 \mathrm{~h}$. The reaction mixture is diluted with EtOAc and washed with $\mathrm{HCl}(1 \mathrm{M})$. After the workup, the residue, corresponding to the 3-aryl-5-hydroxymethyl-1,2,4-thiadiazole (pure by TLC), was used in the next reaction without further purification. Subsequently, a mixture of the corresponding alcohol (1 equiv) and $\mathrm{MnO}_{2}(10$ equiv) in $\mathrm{CHCl}_{3}(12 \mathrm{~mL} / \mathrm{mmol})$ as solvent was heated at reflux until absence of the alcohol (checked by TLC). The resulting dispersion was then filtered through a short pad of Celite, the organic phase concentrated in vacuo and the residue purified by column chromatography $\left(\mathrm{SiO}_{2}\right.$, petroleum ether/EtOAc $\left.(8: 2)\right)$ to afford spectroscopically pure compounds.

5-Hydroxymethyl-3-phenyl-1,2,4-thiadiazole. ${ }^{1} \mathrm{H} \mathrm{NMR}\left(\mathrm{CDCl}_{3}\right)$ $\delta: 2.83(\mathrm{t}, 1 \mathrm{H}), 5.17(\mathrm{~d}, 2 \mathrm{H}, J=5.5 \mathrm{~Hz}), 7.45-7.51(\mathrm{~m}, 3 \mathrm{H})$, 8.24-8.30 (m, 2H). EI-MS, $\mathrm{m} / z$ (abundance, \%): $192\left(\mathrm{M}^{+\bullet}, 38\right)$, 135 (100), 103 (24), 77 (20).

5-Formyl-3-phenyl-1,2,4-thiadiazole (9). Yellow solid, $0.13 \mathrm{~g}$ (25\%, two steps). ${ }^{1} \mathrm{H}$ NMR $\left(\mathrm{CDCl}_{3}\right) \delta: 7.52(\mathrm{~m}, 3 \mathrm{H}), 8.33(\mathrm{~m}, 2 \mathrm{H})$, $10.19(\mathrm{~s}, 1 \mathrm{H}) .{ }^{13} \mathrm{C} \mathrm{NMR}\left(\mathrm{CDCl}_{3}\right) \delta: 184.3(\mathrm{C} 5), 182.5(\mathrm{CHO})$, 175.1 (C3), 131.9 (Cq), $131.0(\mathrm{Co}), 128.9(\mathrm{Cm}), 128.3$ (Cp). EIMS, $m / z$ (abundance, \%): $190\left(\mathrm{M}^{+\bullet}, 84\right), 135$ (100), 103 (30), 77 (24).

3-(4-Chlorophenyl)-5-hydroxymethyl-1,2,4-thiadiazole. ${ }^{1} \mathrm{H}$ NMR $\left(\mathrm{CDCl}_{3}\right) \delta: 2.70(\mathrm{~s}, 1 \mathrm{H}), 5.05(\mathrm{~s}, 2 \mathrm{H}), 7.38(\mathrm{~d}, 2 \mathrm{H}, J=8.5 \mathrm{~Hz})$, $8.15(\mathrm{~d}, 2 \mathrm{H}, J=8.5 \mathrm{~Hz})$. EI-MS, $\mathrm{m} / \mathrm{z}$ (abundance, \%): $226\left(\mathrm{M}^{+\bullet}\right.$, 51), 169 (100), 137 (35), 102 (15).

3-(4-Chlorophenyl)-5-formyl-1,2,4-thiadiazole (18). Yellow solid, $0.28 \mathrm{~g}$ (44\%, two steps). ${ }^{1} \mathrm{H}$ NMR (DMSO- $\left.d_{6}\right) \delta: 7.67$ (d, $2 \mathrm{H}, J=$ $8.5 \mathrm{~Hz}), 8.28(\mathrm{~d}, 2 \mathrm{H}, J=8.7 \mathrm{~Hz}), 10.16(\mathrm{~s}, 1 \mathrm{H}) .{ }^{13} \mathrm{C}$ NMR (DMSO$\left.d_{6}\right) \delta: 180.2(\mathrm{CHO}), 179.1(\mathrm{C} 5), 173.52(\mathrm{C} 3), 137.6(\mathrm{Cq}), 132.7$ (Cq), $130.6(\mathrm{Co}), 130.0(\mathrm{Cm})$. EI-MS, m/z (abundance, \%): 224 $\left(\mathrm{M}^{+}, 75\right), 169$ (100), 137 (39), 102 (18).

5-Hydroxymethyl-3-(4-methoxyphenyl)-1,2,4-thiadiazole. ${ }^{1} \mathrm{H}$ NMR $\left(\mathrm{CDCl}_{3}\right) \delta: 2.75(\mathrm{~s}, 1 \mathrm{H}), 3.87(\mathrm{~s}, 3 \mathrm{H}), 5.15(\mathrm{~s}, 2 \mathrm{H}), 7.01(\mathrm{~d}, 2 \mathrm{H}, J$ $=8.6 \mathrm{~Hz}), 8.42(\mathrm{~d}, 2 \mathrm{H}, J=8.6 \mathrm{~Hz})$. EI-MS, $\mathrm{m} / \mathrm{z}$ (abundance, $\%)$ : $222\left(\mathrm{M}^{+\bullet}, 49\right), 167$ (100), 135 (57).

5-Formyl-3-(4-methoxyphenyl)-1,2,4-thiadiazole (20). Yellow solid, $0.13 \mathrm{~g}$ (31\%, two steps). ${ }^{1} \mathrm{H}$ NMR $\left(\mathrm{CDCl}_{3}\right) \delta: 3.85$ (s, 3H), 7.04 (d, 2H, $J=8.6 \mathrm{~Hz}), 8.31$ (d, 2H, $J=8.7 \mathrm{~Hz}), 10.19(\mathrm{~s}, 1 \mathrm{H})$. ${ }^{13} \mathrm{C} \mathrm{NMR}\left(\mathrm{CDCl}_{3}\right) \delta: 181.2(\mathrm{CHO}), 178.3$ (C5), 172.3 (C3), 160.9 (Cp), $130.1(\mathrm{Co}), 114.5(\mathrm{Cm}), 54.9\left(\mathrm{OCH}_{3}\right)$. EI-MS, $\mathrm{m} / \mathrm{z}$ (abundance, \%): $220\left(\mathrm{M}^{+\bullet}, 99\right), 165$ (100), 150 (45), 133 (75).

3-(3,5-Di-tert-butyl-4-hydroxyphenyl)-5-hydroxymethyl-1,2,4thiadiazole. ${ }^{1} \mathrm{H}$ NMR $\left(\mathrm{CDCl}_{3}\right) \delta: 1.52(\mathrm{~s}, 18 \mathrm{H}), 2.93(\mathrm{~s}, 1 \mathrm{H}), 5.16$ (s, 2H), $5.53(\mathrm{~s}, 1 \mathrm{H}), 8.14(\mathrm{~s}, 2 \mathrm{H})$. ESI-MS, $m / z: 321\left(\mathrm{M}^{+\bullet}+\mathrm{H}\right)$.

3-(3,5-Di-tert-butyl-4-hydroxyphenyl)-5-formyl-1,2,4-thiadiazole (21). Brown solid, $0.14 \mathrm{~g}\left(27 \%\right.$, two steps). ${ }^{1} \mathrm{H}$ NMR $\left(\mathrm{CDCl}_{3}\right)$ $\delta: 1.54(\mathrm{~s}, 18 \mathrm{H}), 5.61(\mathrm{~s}, 1 \mathrm{H}), 8.21(\mathrm{~s}, 2 \mathrm{H}), 10.23(\mathrm{~s}, 1 \mathrm{H}),{ }^{13} \mathrm{C}$ NMR $\left(\mathrm{CDCl}_{3}\right) \delta: 183.9(\mathrm{C} 5), 182.8(\mathrm{CHO}), 175.9(\mathrm{C} 3), 156.6(\mathrm{Cp})$, $136.4(\mathrm{Cm}), 125.7(\mathrm{Co}), 125.3(\mathrm{Cq}), 34.4\left(\mathrm{C}\left(\mathrm{CH}_{3}\right)_{3}\right), 30.2$ $\left(\underline{\mathrm{C}}\left(\mathrm{CH}_{3}\right)_{3}\right)$. ESI-MS, m/z: $319\left(\mathrm{M}^{+\bullet}+\mathrm{H}\right)$.

5-Ethoxycarbonyl-4-methyl-1,2,3-thiadiazole (22). A mixture of ethyl acetoacetate $(4.9 \mathrm{~mL}, 38.5 \mathrm{mmol})$, methyl carbazate $(3.8 \mathrm{~g}$, $42.4 \mathrm{mmol})$, and $p$-TsOH (catalytic amounts) in toluene $(120.0 \mathrm{~mL})$ was heated at reflux for $2 \mathrm{~h}$. Then the solvent was concentrated in vacuo and the crude of the reaction was used in the next reaction without further purification. The acylhydrazone obtained was cooled at $0{ }^{\circ} \mathrm{C}$, and $\mathrm{SOCl}_{2}(20.0 \mathrm{~mL}, 270 \mathrm{mmol})$ was added dropwise with stirred during $10 \mathrm{~min}$. The final mixture was stirred during $2 \mathrm{~h}$ at $60{ }^{\circ} \mathrm{C}$, the excess of $\mathrm{SOCl}_{2}$ was evaporated in vacuo, and the residue was neutralized with aqueous saturated $\mathrm{NaHCO}_{3}$ and extracted with EtOAc $(3 \times 10 \mathrm{~mL})$. After the workup the organic solvent was evaporated in vacuo and the crude purified by column chromatography $\left(\mathrm{SiO}_{2}\right.$, petroleum ether/EtOAc (8:2)), yellow oil, $1.63 \mathrm{~g}$ (25\%). ${ }^{1} \mathrm{H}$ NMR $\left(\mathrm{CDCl}_{3}\right) \delta: 1.55(\mathrm{t}, 3 \mathrm{H}), 2.95(\mathrm{~s}, 3 \mathrm{H}), 4.42(\mathrm{q}$, $2 \mathrm{H}) .{ }^{13} \mathrm{C} \mathrm{NMR}\left(\mathrm{CDCl}_{3}\right) \delta: 162.5(\mathrm{C} 4), 160.1(\mathrm{C}=\mathrm{O}), 139.8(\mathrm{C} 5)$, $62.8\left(\mathrm{CH}_{2} \mathrm{CH}_{3}\right), 14.5\left(\mathrm{CH}_{2} \mathrm{CH}_{3}+\mathrm{CH}_{3}\right)$. ESI-MS, m/z: $173.0\left(\mathrm{M}^{+} \cdot\right.$ $+\mathrm{H})$.

5-Hydroxymethyl-4-methyl-1,2,3-thiadiazole (23). A solution of $22(0.8 \mathrm{~g}, 4.7 \mathrm{mmol})$ in $\mathrm{EtOH}(8.0 \mathrm{~mL})$ was cooled at $0{ }^{\circ} \mathrm{C}$. Then $\mathrm{NaBH}_{4}(0.3 \mathrm{~g}, 7.9 \mathrm{mmol})$ was added slowly and the final mixture was stirred during $2 \mathrm{~h}$ at room temperature. The organic solvent was evaporated in vacuo, and the residue was treated with $\mathrm{H}_{2} \mathrm{O}$ $(50.0 \mathrm{~mL})$ and extracted with EtOAc $(3 \times 10.0 \mathrm{~mL})$. After the 
workup the organic solvent was evaporated in vacuo. The residue was purified by column chromatography $\left(\mathrm{SiO}_{2}\right.$, petroleum ether/ EtOAc (7:3)), yielding derivative 23 as a yellow oil $(0.42 \mathrm{~g}, 70 \%)$. ${ }^{1} \mathrm{H} \mathrm{NMR}\left(\mathrm{CDCl}_{3}\right) \delta: 2.55(\mathrm{~s}, 3 \mathrm{H}), 4.55(\mathrm{bs}, 1 \mathrm{H}), 4.94(\mathrm{~s}, 2 \mathrm{H}),{ }^{13} \mathrm{C}$ NMR $\left(\mathrm{CDCl}_{3}\right) \delta: 154.4(\mathrm{C} 5), 152.9(\mathrm{C} 4), 56.3\left(\mathrm{CH}_{2} \mathrm{OH}\right), 12.1$ $\left(\mathrm{CH}_{3}\right)$. ESI-MS, $m / z: 131\left(\mathrm{M}^{+\bullet}+\mathrm{H}\right)$.

5-Formyl-4-methyl-1,2,3-thiadiazole (24). A mixture of 23 (0.49 $\mathrm{g}, 3.77 \mathrm{mmol})$ and $\mathrm{MnO}_{2}(3.28 \mathrm{~g}, 37.7 \mathrm{mmol})$ in $\mathrm{CHCl}_{3}(45 \mathrm{~mL})$ as solvent is heated at reflux until absence of the alcohol $\mathbf{2 3}$ (checked by TLC). The resulting dispersion was then filtered through a short pad of Celite, the organic phase concentrated in vacuo, and the residue purified by column chromatography $\left(\mathrm{SiO}_{2}\right.$, petroleum ether/EtOAc (8:2)), yielding derivative $\mathbf{2 4}$ as a yellow oil $(105 \mathrm{mg}, 26 \%) .{ }^{1} \mathrm{H}$ NMR $\left(\mathrm{CDCl}_{3}\right) \delta: 3.05(\mathrm{~s}, 3 \mathrm{H}), 10.26(\mathrm{~s}$, 1H). ${ }^{13} \mathrm{C} \mathrm{NMR}\left(\mathrm{CDCl}_{3}\right) \delta: 184.3(\mathrm{CHO}), 156.2$ (C5), 154.2 (C4), $14.4\left(\mathrm{CH}_{3}\right)$. ESI-MS, $m / z: 129\left(\mathrm{M}^{+\bullet}+\mathrm{H}\right)$.

5-Ethoxycarbonyl-4-formyl-1,2,3-thiadiazole (25). A mixture of 22 (1.0 g, $5.8 \mathrm{mmol}), N$-bromosuccinimide $(1.14 \mathrm{~g}, 6.4 \mathrm{mmol})$, and dibenzoyl peroxide $(0.06 \mathrm{~g}, 0.23 \mathrm{mmol})$ in dry $\mathrm{CCl}_{4}(40.0 \mathrm{~mL})$ was heated at reflux for $16 \mathrm{~h}$. Then the mixture was allowed to cool to room temperature, the succinimide was collected and washed with $\mathrm{CCl}_{4}$, and the organic layer was evaporated in vacuo. DMSO $(10.0 \mathrm{~mL})$ was added, and the mixture was warmed at $120^{\circ} \mathrm{C}$ during $3 \mathrm{~h}$. Then EtOAc $(50 \mathrm{~mL})$ was added and the organic layer was washed with saturated sodium chloride solution $(40.0 \mathrm{~mL})$. After the workup the organic solvent was evaporated in vacuo and the residue purified by column chromatography $\left(\mathrm{SiO}_{2}\right.$, petroleum ether/ EtOAc (8:2)), yielding a yellow oil that crystallized at $4{ }^{\circ} \mathrm{C}(0.4 \mathrm{~g}$, 40\%). ${ }^{1} \mathrm{H}$ NMR $\left(\mathrm{CDCl}_{3}\right) \delta: 1.48(\mathrm{t}, 3 \mathrm{H}), 4.56(\mathrm{q}, 2 \mathrm{H}), 10.67(\mathrm{~s}$, 1H). ${ }^{13} \mathrm{C} \mathrm{NMR}\left(\mathrm{CDCl}_{3}\right) \delta: 186.1(\mathrm{CHO}), 157.2(\mathrm{C} 4), 161.8(\mathrm{C}=\mathrm{O})$, 141.5 (C5), $64.2\left(\mathrm{CH}_{2} \mathrm{CH}_{3}\right), 14.1\left(\mathrm{CH}_{2} \mathrm{CH}_{3}\right)$. ESI-MS, m/z: 187 $\left(\mathrm{M}^{+\bullet}+\mathrm{H}\right)$.

General Procedure for the Synthesis of $\alpha$-Heteroaryl- $N$-alkylnitrone Derivatives (30-41). A mixture of the corresponding aldehyde (1 equiv), $\mathrm{N}$-alkylhydroxylamine hydrochloride (1.5 equiv), and sodium bicarbonate (1.5 equiv) in absolute ethanol (6 $\mathrm{mL} / \mathrm{mmol}$ ) as solvent was heated at $60{ }^{\circ} \mathrm{C}$ until the carbonyl compound was not present (checked by TLC). The solvent was removed in vacuo and the reaction mixture diluted with $\mathrm{H}_{2} \mathrm{O}$ and extracted with EtOAc. After the workup of the combined organic layers, the residue was purified by column chromatography $\left(\mathrm{SiO}_{2}\right.$, mixtures of petroleum ether/EtOAc).

$\alpha(Z)$-(5-Phenyl-1,2,4-thiadiazol-3-yl)-N-tert-butylnitrone (30). Yellow solid (87\%); mp 111.0-113.0 ${ }^{\circ} \mathrm{C} ;{ }^{1} \mathrm{H}$ NMR $\left(\mathrm{CDCl}_{3}\right) \delta: 1.63$ (s, 9H), 7.48-7.56 (m, 3H), 7.97 (d, 2H), 8.18 (s, 1H). ${ }^{13} \mathrm{C}$ NMR $\left(\mathrm{CDCl}_{3}\right) \delta: 187.4(\mathrm{C} 5), 166.5(\mathrm{C} 3), 132.1(\mathrm{Cp}), 129.3(\mathrm{Cm}), 127.5$ (Co), $123.2(\mathrm{CH}=\mathrm{N}), 73.0\left(\underline{\mathrm{C}}\left(\mathrm{CH}_{3}\right)_{3}\right), 28.3\left(\mathrm{C}\left(\mathrm{CH}_{3}\right)_{3}\right)$. ESI-MS, $m / z: 262\left(\mathrm{M}^{+\bullet}+\mathrm{H}\right)$. IR $(\mathrm{KBr}) v: 1707,1561,1469,1435,1248$, 1152, 773, 695. Anal. Calcd for $\left(\mathrm{C}_{13} \mathrm{H}_{15} \mathrm{~N}_{3} \mathrm{OS}\right)$ : C, 59.74; $\mathrm{H}, 5.79$; N, 16.08; S, 12.27. Found: C, 59.46; H, 5.86; N, 15.97; S, 12.27.

$\alpha(Z)$-(3-Phenyl-1,2,4-thiadiazol-5-yl)- $N$-tert-butylnitrone (31). Yellow solid (82\%); $\mathrm{mp} 107.0-108.0{ }^{\circ} \mathrm{C} .{ }^{1} \mathrm{H}$ NMR $\left(\mathrm{CDCl}_{3}\right) \delta: 1.66$ (s, 9H), 7.44-7.50 (m, 3H), 8.29-8.32 (m, 2H), $8.63(\mathrm{~s}, 1 \mathrm{H}) .{ }^{13} \mathrm{C}$ NMR $\left(\mathrm{CDCl}_{3}\right) \delta: 175.8$ (C5), $172.0(\mathrm{C} 3), 133.2(\mathrm{Cq}), 130(\mathrm{Co})$, $128.9(\mathrm{Cm}), 128.2(\mathrm{Cp}), 126.1(\mathrm{CH}=\mathrm{N}), 71.9\left(\mathrm{C}\left(\mathrm{CH}_{3}\right)_{3}\right), 28.3$ $\left(\mathrm{C}\left(\mathrm{CH}_{3}\right)_{3}\right)$. EI-MS, $\mathrm{m} / z$ (abundance, \%): $261\left(\mathrm{M}^{+\cdot}, 16\right), 205(42)$, 135 (19), 103 (19), 57 (100). IR (KBr) $v: 1544,1470,1414,1344$, 1234, 1112, 913, 716, 696, 558. Anal. Calcd for $\left(\mathrm{C}_{13} \mathrm{H}_{15} \mathrm{~N}_{3} \mathrm{OS}\right): \mathrm{C}$, 59.74; H, 5.79; N, 16.08; S, 12.27. Found: C, 59.35; H, 5.74; N 15.89; S, 12.08 .

$\alpha(Z)$-(3-Phenyl-1,2,4-thiadiazol-5-yl)- $N$-cyclohexylnitrone (32). Yellow solid (86\%); mp 194.0-196.0 ${ }^{\circ} \mathrm{C} .{ }^{1} \mathrm{H}$ NMR $\left(\mathrm{CDCl}_{3}\right) \delta$ : $1.21-1.50(\mathrm{~m}, 5 \mathrm{H}), 1.99-2.20(\mathrm{~m}, 5 \mathrm{H}), 4.16(\mathrm{~m}, 1 \mathrm{H}), 7.52-7.47$ $(\mathrm{m}, 3 \mathrm{H}), 8.34-8.31(\mathrm{~m}, 2 \mathrm{H}), 8.51(\mathrm{~s}, 1 \mathrm{H}) .{ }^{13} \mathrm{C} \mathrm{NMR}\left(\mathrm{CDCl}_{3}\right) \delta$ : 175.4 (C5), 172.2 (C3), 133.4 (Cq), $130.6(\mathrm{Co}), 129.1(\mathrm{Cm}), 128.5$ $(\mathrm{Cp}), 128.0(\mathrm{CH}=\mathrm{N}), 74.9\left(\mathrm{CCH}_{2}\right), 31.7\left(\mathrm{CCH}_{2}\right), 25.3\left(\mathrm{CH}_{2} \mathrm{CH}_{2}\right)$. EI-MS, $m / z$ (abundance, \%): $287\left(\mathrm{M}^{+\bullet}, 79\right), 269$ (32), 243 (25), 205 (86), 189 (31), 135 (60), 103 (42), 55 (100). IR (KBr) v: 1551, 1465, 1432, 1352, 926. Anal. Calcd for $\left(\mathrm{C}_{15} \mathrm{H}_{17} \mathrm{~N}_{3} \mathrm{OS}\right)$ : $\mathrm{C}, 62.69$; H, 5.96; N, 14.62; S, 11.16. Found: C, 62.39; H, 5.78; N, 14.55; S, 10.98 .
$\alpha(Z)$-(3-Phenyl-1,2,4-thiadiazol-5-yl)- $N$-benzylnitrone (33). White solid (65\%); mp 156.0-158.0 ${ }^{\circ} \mathrm{C} .{ }^{1} \mathrm{H}$ NMR $\left(\mathrm{CDCl}_{3}\right) \delta$ : 5.21 (s, 2H), 7.46-7.45 (m, 3H), $7.48(\mathrm{~s}, 5 \mathrm{H}), 8.30-8.27(\mathrm{~m}, 2 \mathrm{H}), 8.35$ $(\mathrm{s}, 1 \mathrm{H}) .{ }^{13} \mathrm{C} \mathrm{NMR}\left(\mathrm{CDCl}_{3}\right) \delta$ : $174.9(\mathrm{C} 5), 171.9(\mathrm{C} 3), 132.8(\mathrm{Cq})$, $130.9(\mathrm{Cq}), 130.3$ (Co), $129.9(\mathrm{Cm}), 128.8(\mathrm{Co}), 129.5(\mathrm{Cm}), 129.4$ $(\mathrm{Cp}), 128.7(\mathrm{Cp}), 128.0(\mathrm{CH}=\mathrm{N}), 69.5\left(\mathrm{CH}_{2}\right)$. EI-MS, $\mathrm{m} / \mathrm{z}$ (abundance, \%): $295\left(\mathrm{M}^{+\bullet}, 32\right), 278$ (4), 135 (5), 103 (7), 91 (100). IR (KBr) $v: 1534,1465,1423,1323,1234,1130,919,726$. Anal. Calcd for $\left(\mathrm{C}_{16} \mathrm{H}_{13} \mathrm{~N}_{3} \mathrm{OS}\right)$ : C, 65.06; H, 4.44; N, 14.23; S, 10.86 . Found: C, 64.88; H, 4.30; N, 14.12; S, 10.61.

$\alpha(Z)$-[3-(4-Chlorophenyl)-1,2,4-thiadiazol-5-yl]- $N$-tert-butylnitrone (34). Yellow solid (68\%); mp 129.0-131.0 ${ }^{\circ} \mathrm{C} .{ }^{1} \mathrm{H}$ NMR $\left(\mathrm{CDCl}_{3}\right) \delta: 1.68(\mathrm{~s}, 9 \mathrm{H}), 7.46(\mathrm{~d}, 2 \mathrm{H}, J=8.5 \mathrm{~Hz}), 8.27(\mathrm{~d}, 2 \mathrm{H}, J$ $=8.5 \mathrm{~Hz}), 8.63(\mathrm{~s}, 1 \mathrm{H}) \cdot{ }^{13} \mathrm{C} \mathrm{NMR}\left(\mathrm{CDCl}_{3}\right) \delta: 175.7$ (C5), 170.7 (C3), 136.2 (Cp), 131.5 (Cq), 129.3 (Co), 128.9 (Cm), 125.8 $(\mathrm{CH}=\mathrm{N}), 71.7\left(\mathrm{C}\left(\mathrm{CH}_{3}\right)_{3}\right), 28.1\left(\mathrm{C}\left(\mathrm{CH}_{3}\right)_{3}\right)$. EI-MS, $\mathrm{m} / \mathrm{z}$ (abundance, \%): $295\left(\mathrm{M}^{+\bullet}, 26\right), 239$ (35), $169(\overline{8}), 137$ (14), 57 (100). IR (KBr) $v: 1548,1471,1420,1404,1346,1236,1118,913,838,741,558$. Anal. Calcd for $\left(\mathrm{C}_{13} \mathrm{H}_{14} \mathrm{ClN}_{3} \mathrm{OS}\right)$ : C, 52.79; H, 4.77; N, 14.21; S, 10.84. Found: C, 52.78; H, 5.07; N, 14.02; S, 11.01.

$\alpha(Z)$-[3-(4-Methoxyphenyl)-1,2,4-thiadiazol-5-yl]-N-tert-butylnitrone (35). Orange solid (88\%); mp 130.0-132.0 ${ }^{\circ} \mathrm{C}$. ${ }^{1} \mathrm{H}$ NMR $\left(\mathrm{CDCl}_{3}\right) \delta: 1.67(\mathrm{~s}, 9 \mathrm{H}), 3.87(\mathrm{~s}, 3 \mathrm{H}), 7.01(\mathrm{~d}, 2 \mathrm{H}, J=8.7 \mathrm{~Hz})$, $8.28(\mathrm{~m}, 2 \mathrm{H}, J=8.8 \mathrm{~Hz}), 8.63(\mathrm{~s}, 1 \mathrm{H}) .{ }^{13} \mathrm{C} \mathrm{NMR}\left(\mathrm{CDCl}_{3}\right) \delta: 175.4$ (C5), 171.6 (C3), 161.2 (Cp), $129.5(\mathrm{Co}), 125.9(\mathrm{CH}=\mathrm{N}), 114.0$ $(\mathrm{Cm}), 71.6\left(\underline{\mathrm{C}}\left(\mathrm{CH}_{3}\right)_{3}\right), 55.3\left(\mathrm{OCH}_{3}\right), 28.0\left(\mathrm{C}\left(\mathrm{CH}_{3}\right)_{3}\right)$. EI-MS, $\mathrm{m} / \mathrm{z}$ (abundance, \%): $291\left(\mathrm{M}^{+\bullet}, 91\right), 235$ (100), 165 (26), 133 (38), 57 (89). IR (KBr) v: 1609, 1547, 1408,1314, 1246, 1180, 1026, 838, 750, 659, 556. Anal. Calcd for $\left(\mathrm{C}_{14} \mathrm{H}_{17} \mathrm{~N}_{3} \mathrm{O}_{2} \mathrm{~S}\right)$ : C, 57.71; H, 5.88; N, 14.42; S, 11.00. Found: C, 56.56; H, 5.68; N, 14.23; S, 10.80. $\alpha(Z)$-[3-(3,5-Di-tert-butyl-4-hydroxyphenyl)-1,2,4-thiadiazol-5yl]- $N$-tert-butylnitrone (36). Yellow solid (92\%); mp 292.0-294.0 ${ }^{\circ} \mathrm{C} .{ }^{1} \mathrm{H} \mathrm{NMR}\left(\mathrm{CDCl}_{3}\right) \delta: 1.51(\mathrm{~s}, 18 \mathrm{H}), 1.68(\mathrm{~s}, 9 \mathrm{H}), 5.48(\mathrm{~s}, 1 \mathrm{H})$, 8.19 (s, 2H), 8.64 (s, 1H). ${ }^{13} \mathrm{C} \mathrm{NMR}\left(\mathrm{CDCl}_{3}\right) \delta: 175.2$ (C5), 172.7 (C3), $155.9(\mathrm{Cp}), 136.1(\mathrm{Cq}), 126.0(\mathrm{Co}), 125.2(\mathrm{CH}=\mathrm{N}), 124.6$ $(\mathrm{Cm}), 71.5\left(\underline{\mathrm{C}}\left(\mathrm{CH}_{3}\right)_{3}\right), 34.4\left(\underline{\mathrm{C}}\left(\mathrm{CH}_{3}\right)_{3}\right), 30.3\left(\mathrm{C}_{(}\left(\mathrm{CH}_{3}\right)_{3}\right), 28.4$ $\left(\mathrm{C}\left(\mathrm{CH}_{3}\right)_{3}\right)$. EI-MS, $m / z$ (abundance, \%): $389\left(\mathrm{M}^{+\bullet}, 87\right), 374$ (46), 333 (36), 318 (100), 57 (40). IR (KBr) v: 3593, 2961, 1544, 1398, 1254, 1236, 1121, 913, 747, 696, 555. Anal. Calcd for $\left(\mathrm{C}_{21} \mathrm{H}_{31} \mathrm{~N}_{3} \mathrm{O}_{2} \mathrm{~S}\right)$ : C, 64.75; H, 8.02; N, 10.79; S, 8.23. Found: $\mathrm{C}$, 64.50; H, 8.30; N, 10.63; S, 8.18.

$\alpha(Z)$-(4-Methyl-1,2,3-thiadiazol-5-yl)- $N$-tert-butylnitrone (37). Beige solid (77\%); mp 154.0-156.0 ${ }^{\circ} \mathrm{C} .{ }^{1} \mathrm{H} \mathrm{NMR}\left(\mathrm{CDCl}_{3}\right) \delta: 1.67$ $(\mathrm{s}, 9 \mathrm{H}), 2.85(\mathrm{~s}, 3 \mathrm{H}), 8.20(\mathrm{~s}, 1 \mathrm{H}),{ }^{13} \mathrm{C} \mathrm{NMR}\left(\mathrm{CDCl}_{3}\right) \delta: 157.7$ (C5), $138.4(\mathrm{C} 4), 122.7(\mathrm{CH}=\mathrm{N}), 71.2\left(\underline{\mathrm{C}}\left(\mathrm{CH}_{3}\right)_{3}\right), 28.5\left(\mathrm{C}\left(\mathrm{CH}_{3}\right)_{3}\right)$, $13.9\left(\mathrm{CH}_{3}\right)$. EI-MS, $m / z$ (abundance, \%): $199\left(\mathrm{M}^{+}, 2\right), 1 \overline{7} 1$ (2), 123 (30), 108 (42), 57 (100). IR (KBr) v: 3136, 2997, 2972, 1547, 1493, 1439, 1361, 1323, 1201,1140, 1035, 887, 827, 723, 572. Anal. Calcd for $\left(\mathrm{C}_{8} \mathrm{H}_{13} \mathrm{~N}_{3} \mathrm{O}_{2} \mathrm{~S}\right)$ : C, 48.22; H, 6.58; N, 21.09; S, 16.09. Found: C, 48.09; H, 6.30; N, 20.82; S, 15.88 .

$\alpha(Z)$-(5-Ethoxycarbonyl-1,2,3-thiadiazol-4-yl)- $\mathrm{N}$-tert-butylnitrone (38). Yellow solid $(48 \%)$; $\mathrm{mp} 93.0-95.0{ }^{\circ} \mathrm{C} .{ }^{1} \mathrm{H}$ NMR $\left(\mathrm{CDCl}_{3}\right)$ $\delta: 1.44$ (t, 3H), 1.65 (s, 9H), 4.48 (q, 2H), 8.52 (s, 1H). ${ }^{13} \mathrm{C}$ NMR $\left(\mathrm{CDCl}_{3}\right) \delta: 159.9(\mathrm{C}=\mathrm{O}), 153.9(\mathrm{C} 4), 143.2(\mathrm{C} 5), 121.2(\mathrm{CH}=\mathrm{N})$,

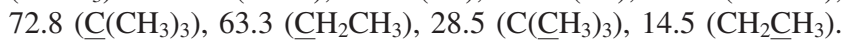
EI-MS, $m / z$ (abundance, \%): $257\left(\mathrm{M}^{+\bullet}, 1\right), 201$ (9), 173 (9), 127 (6), 57 (100). IR (KBr) v: 3147, 299, 1732, 1562, 1535, 1394, 1313, 1209, 1153, 1087, 910, 860, 767, 559. Anal. Calcd for $\left(\mathrm{C}_{10} \mathrm{H}_{15} \mathrm{~N}_{3} \mathrm{O}_{3} \mathrm{~S}\right): \mathrm{C}, 46.68 ; \mathrm{H}, 5.88 ; \mathrm{N}, 16.33 ; \mathrm{S}, 12.46$. Found: $\mathrm{C}$, 46.33; H, 5.50; N, 16.20; S, 12.19 .

$\alpha(Z)$-(4-Phenylfuroxan-3-yl)- $N$-tert-butylnitrone (39). Yellow solid (57\%); mp 78.0-80.0 ${ }^{\circ} \mathrm{C} .{ }^{1} \mathrm{H}$ NMR $\left(\mathrm{CDCl}_{3}\right) \delta: 1.61(\mathrm{~s}, 9 \mathrm{H})$, $7.42-7.56(\mathrm{~m}, 5 \mathrm{H}), 7.58(\mathrm{~s}, 1 \mathrm{H}) .{ }^{13} \mathrm{C} \mathrm{NMR}\left(\mathrm{CDCl}_{3}\right) \delta: 155.8(\mathrm{C} 4)$, $133.9(\mathrm{Cm}), 130.5(\mathrm{Co}), 126.7(\mathrm{Cp}), 114.9(\mathrm{CH}=\mathrm{N}), 110.3(\mathrm{C} 3)$,

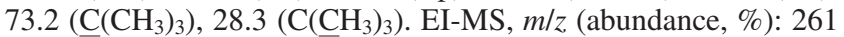
$\left(\mathrm{M}^{+\bullet}, 2\right), 205$ (18), 145 (10), 105 (18), 57 (100). IR (KBr) v: 3138, 2979, 2935, 1600, 1560, 1456, 1382, 1247, 1199, 1139, 1028, 983, 858, 812, 709, 556. Anal. Calcd for $\left(\mathrm{C}_{13} \mathrm{H}_{15} \mathrm{~N}_{3} \mathrm{O}_{3}\right): \mathrm{C}, 59.76 ; \mathrm{H}$, 5.79; N, 16.08. Found: C, 59.45; H, 5.61; N, 15.87 .

$\alpha(Z)$-(3-Methylfuroxan-4-yl)- $N$-tert-butylnitrone (40). Yellow solid (81\%); mp $119.0-121.0{ }^{\circ} \mathrm{C} .{ }^{1} \mathrm{H}$ NMR $\left(\mathrm{CDCl}_{3}\right) \delta: 1.61$ (s, 
9H), 2.33 (s, 3H), 7.96(s, 1H). ${ }^{13} \mathrm{C}$ NMR $\left(\mathrm{CDCl}_{3}\right) \delta: 151.1$ (C4),

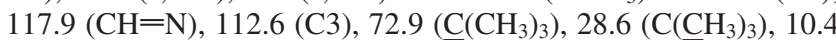
$\left(\mathrm{CH}_{3}\right)$. EI-MS, $\mathrm{m} / \mathrm{z}$ (abundance, \%): $199\left(\mathrm{M}^{+\bullet}, 3\right), 143$ (9), 113 (6), 83 (4), 57 (100). IR (KBr) v: 2984, 1616, 1566, 1457, 1364, 1251, 1178, 1140, 834, 763, 549. Anal. Calcd for $\left(\mathrm{C}_{8} \mathrm{H}_{13} \mathrm{~N}_{3} \mathrm{O}_{3}\right)$ : C, 48.23; H, 6.58; N, 21.09. Found: C, 48.02; H, 6.30; N, 20.92.

$\alpha(Z)$-(Benzofuroxan-5(6)-yl)- $N$-tert-butylnitrone (41). Yellow solid (61\%); mp 112.0-114.0 ${ }^{\circ} \mathrm{C} .{ }^{1} \mathrm{H}$ NMR $\left(\mathrm{CDCl}_{3}\right) \delta: 1.60$ (s, 9H), 7.32 (bs, 1H), 7.50 (bs, 1H), $7.60(\mathrm{~s}, 1 \mathrm{H}), 9.33$ (bs, $1 \mathrm{H}) .{ }^{13} \mathrm{C}$ NMR $\left.\left(\mathrm{CDCl}_{3}\right) \delta: 127.4(\mathrm{CH}=\mathrm{N}), 72.5\left(\mathrm{C}\left(\mathrm{CH}_{3}\right)_{3}\right), 28.3\left(\mathrm{C}_{(\mathrm{CH}}\right)_{3}\right)$. EI-MS, $m / z$ (abundance, \%): $235\left(\mathrm{M}^{+\bullet}, \overline{9}\right), 179(17), 163(\overline{5}), 152$ (6), 57 (100). IR (KBr) v: 2984, 1610, 1570, 1487, 1361, 1236, $1153,1014,868,828,585$. Anal. Calcd for $\left(\mathrm{C}_{11} \mathrm{H}_{13} \mathrm{~N}_{3} \mathrm{O}_{3}\right)$ : C, 56.16; H, 5.57; N, 17.86. Found: C, 55.99; H, 5.34; N, 17.70.

Measurement of Cell Viability. Culture of SH-SY5Y Cells. SH-SY5Y cells, at passages between 3 and 16 after defreezing, were maintained in a minimum essential medium (MEM) containing 15 nonessential amino acids (NEAAs) and supplemented with $10 \%$ fetal bovine serum, $1 \mathrm{mM}$ glutamine, 50 units $/ \mathrm{mL}$ penicillin, and $50 \mu \mathrm{g} / \mathrm{mL}$ streptomycin (reagents from GIBCO, Madrid, Spain). Cultures were seeded into flasks containing supplemented medium and maintained at $37{ }^{\circ} \mathrm{C}$ in $5 \% \mathrm{CO}_{2}$ /humidified air.

Cell Viability Assays. The effects of nitrones on SH-SY5Y cell viability were determined by measuring the activity of LDH released into the culture medium (Cytotox 96 LDH assay, Promega, U.K.). The assay was performed in accordance with the manufacturer's protocol using SH-SY5Y cells seeded at $10^{4}$ cells/well in 96-well plates. Cells were exposed to 10,1 , and $0.05 \mu \mathrm{M}$ of each one nitrone for $24 \mathrm{~h}$

The effects of $\mathrm{H}_{2} \mathrm{O}_{2}$ on SH-SY5Y cell viability were determined by measuring the activity of $\mathrm{LDH}$ released into the culture medium (Cytotox 96 LDH assay, Promega, U.K.). The assay was performed in accordance with the manufacturer's protocol using SH-SY5Y cells seeded at $10^{4}$ cells/well in 96-well plates. Cells were exposed to $10 \mu \mathrm{M}$ of each one heteroarylnitrone for $1 \mathrm{~h}$ and subsequently exposed to $100 \mu \mathrm{M} \mathrm{H}_{2} \mathrm{O}_{2}$ for $24 \mathrm{~h}$. An amount of $5 \mathrm{mM}$ NAC was used as positive test.

Unspecific Mammalian Cytotoxicity. J774 murine macrophagelike cells (ATCC) were maintained by passage in Dulbecco's modified Eagle's medium (DMEM) containing $4 \mathrm{mM}$ L-glutamine and supplemented with $10 \%$ heat-inactivated fetal calf serum. J774 cells were seeded $\left(1 \times 10^{5}\right.$ cells/well $)$ in 96 -well microplates with $100 \mu \mathrm{L}$ of RPMI medium supplemented with fetal serum. Cells were allowed to attach for $48 \mathrm{~h}$ in a humidified $5 \% \mathrm{CO}_{2} / 95 \%$ air atmosphere at $37{ }^{\circ} \mathrm{C}$ and then exposed to nitrones $(50-500 \mu \mathrm{M})$ for $48 \mathrm{~h}$. Afterward, cell viability was assessed by measuring the mitochondrial-dependent reduction of 3-[4,5-dimethylthiazol-2yl]2,5-diphenyltetrazolium bromide (MTT, Sigma) to formazan. For that purpose, MTT was added to cells to a final concentration of $0.2 \mathrm{mg} / \mathrm{mL}$ and cells were incubated at $37^{\circ} \mathrm{C}$ for $3 \mathrm{~h}$. After removal of the media, formazan crystals were dissolved in DMSO, and the absorbance at $560 \mathrm{~nm}$ was read using a microplate spectrophotometer. Results are expressed as $\mathrm{IC}_{50}$ (compound concentration that reduce $50 \%$ control absorbance at $560 \mathrm{~nm}$ ). Every $\mathrm{IC}_{50}$ is the average of two different experiments.

Blood-Brain Barrier Permeation Assay. Brain penetration of new nitrones was evaluated using a parallel artificial membrane permeation assay (PAMPA) in a similar manner as described previously. ${ }^{27}$ Commercial drugs were purchased from Sigma, Aldrich, Acros, and Fluka. Millex filter units (PVDF membrane, diameter $25 \mathrm{~mm}$, pore size $0.45 \mu \mathrm{m}$ ) were acquired from Millipore. The porcine brain lipid (PBL) was obtained from Avanti Polar Lipids. The donor microplate was a 96-well filter plate (PVDF membrane, pore size $0.45 \mu \mathrm{m}$ ), and the acceptor microplate was an indented 96-well plate, both from Millipore. The acceptor 96well microplate was filled with $170 \mu \mathrm{L}$ of PBS/ethanol (9:1), and the filter surface of the donor microplate was impregnated with 4 $\mu \mathrm{L}$ of PBL in dodecane $(20 \mathrm{mg} / \mathrm{mL})$. Compounds were dissolved in PBS/ethanol (9:1) at $1 \mathrm{mg} / \mathrm{mL}$, filtered through a Millex filter, and then added to the donor wells $(170 \mu \mathrm{L})$. The donor filter plate was carefully put on the acceptor plate to form a sandwich, which was left undisturbed for $120 \mathrm{~min}$ at $25^{\circ} \mathrm{C}$. After incubation, the donor plate was carefully removed and the concentration of compounds in the acceptor wells was determined by UV spectroscopy. Every sample was analyzed in four wells and at least in three independent runs, and the results are given as the mean \pm standard deviation.

Determination of Antioxidant Activity. OFRAC ${ }_{\mathrm{FL}}$ Assay. A luminescence spectrometer LS 50B (PerkinElmer, Boston, MA), a heating circulator bath DC1-B3 (Haake Haake Fisons, Karlsruhe, Germany), and quartz cuvettes were used. For the $\mathrm{ORAC}_{\mathrm{FL}}$ assay, the 490-P excitation and 515-P emission filters were used, and the fluorescence measurement was carried out at $60{ }^{\circ} \mathrm{C}$. The method of $\mathrm{Ou}$ et al. ${ }^{29}$ was modified as follows: the reaction was carried

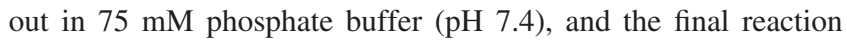
volume was $3000 \mu \mathrm{L}$. Studied compounds $(10-1000 \mu \mathrm{M}$ final concentrations) and fluorescein ( $215 \mu \mathrm{L}, 70 \mathrm{nM}$ final concentration) solutions were placed in the quartz cuvette. The mixture was preincubated for $30 \mathrm{~s}$ at $60{ }^{\circ} \mathrm{C}$. 2,2'-Azobis(2-amidinopropane) dihydrochloride (AAPH) solution $(240 \mu \mathrm{L} ; 12 \mathrm{mM}$, final concentration) was added rapidly using a single channel pipet. The quartz cuvette was immediately placed in the luminescence spectrometer and the fluorescence recorded every minute for $12 \mathrm{~min}$. As a blank FL + AAPH in phosphate buffer instead of the studied compounds solutions were employed, and eight calibration solutions using Trolox (1-8 $\mu \mathrm{M}$, final concentration) as antioxidant positive control were also carried out in each assay. All the reaction mixtures were prepared in duplicate, and at least three independent assays were performed for each sample. Raw data were exported to an OriginPro (OriginLab Corporation, Northampton, MA) sheet for further calculations. Blank and antioxidant curves (fluorescence versus time) were first normalized by dividing original data by fluorescence at $t=0 \mathrm{~s}$. From the normalized curves, the area under the fluorescence decay curve (AUC) was calculated as

$$
\mathrm{AUC}=1+\sum_{i=1}^{i=12} \frac{f_{i}}{f_{0}}
$$

where $f_{0}$ is the initial fluorescence reading at $0 \mathrm{~min}$ and $f_{i}$ is the fluorescence reading at time $i$. The net AUC corresponding to each sample was calculated by subtracting the AUC corresponding to the blank. Regression equations between net AUC and antioxidant concentration were calculated for all the samples. ORAC $\mathrm{FL}_{\mathrm{FL}}$ values were expressed as PBN equivalents by using the standard curve calculated for each assay. Final results were expressed in $\mu$ mole of PBN equivalent per $\mu$ mole of samples.

DPPH Assay. The reaction was carried out in 96-well microplates, and the final reaction mixture was $100 \mu \mathrm{L}$ per well. Antioxidant $(0.1 \mathrm{mM}$, final concentration) and DPPH $(0.1 \mathrm{mM}$, final concentration) were dissolved in $\mathrm{EtOH}$ and preincubated for $5 \mathrm{~min}$ at $37^{\circ} \mathrm{C}$, and the absorbance at $520 \mathrm{~nm}$ was read using a microplate spectrophotometer. The antioxidant activity was determined as the $\mathrm{RP}$ of DPPH, calculated as follows: $\mathrm{RP}=100\left[\left(A_{0}-A_{c}\right) / A_{0}\right]$, where $A_{0}$ is the untreated DPPH absorbance and $A_{c}$ is the value for added sample concentration $c$.

ESR Spectroscopy. The spin trapping ability of the developed heteroarylnitrones was studied by ESR spectroscopy. ESR spectra were recorded in the $\mathrm{X}$ band $(9.85 \mathrm{GHz})$ using a Bruker ECS 106 spectrometer with a rectangular cavity and $50 \mathrm{kHz}$ field modulation. All the spectra were registered in the same scale after 15 scans. The hyperfine splitting constants were estimated to be accurate within $0.05 \mathrm{G}$.

Generation of Free Radicals. Hydroxyl radical $\left({ }^{\circ} \mathrm{OH}\right)$ was generated from a standard Fenton system: $\mathrm{Fe}\left(\mathrm{NH}_{4}\right)_{2}\left(\mathrm{SO}_{4}\right)_{2} \cdot 6 \mathrm{H}_{2} \mathrm{O}$ (50 $\mu \mathrm{L}, 0.5 \mathrm{mM})$ was added to a solution of nitrone $(50 \mathrm{mM}$, final concentration) and $\mathrm{H}_{2} \mathrm{O}_{2}(50 \mu \mathrm{L}, 0.5 \mathrm{mM})$ in phosphate buffer (final reaction mixture was $250 \mu \mathrm{L})$. Cysteinyl radical $\left(\mathrm{SO}_{3}{ }^{-}\right)$was generated from a standard Fenton system: $\mathrm{Fe}\left(\mathrm{NH}_{4}\right)_{2}\left(\mathrm{SO}_{4}\right)_{2} \cdot 6 \mathrm{H}_{2} \mathrm{O}$ $(50 \mu \mathrm{L}, 0.5 \mathrm{mM})$ was added to a solution of nitrone $(50 \mathrm{mM}$, final concentration), $\mathrm{Na}_{2} \mathrm{SO}_{3}(50 \mu \mathrm{L}, 250 \mathrm{mM})$, and $\mathrm{H}_{2} \mathrm{O}_{2}(50 \mu \mathrm{L}, 0.5$ $\mathrm{mM}$ ) in phosphate buffer (final reaction mixture was $250 \mu \mathrm{L}$ ). 
Ethanol radical $\left(\mathrm{CH}_{3}{ }^{\circ} \mathrm{CHOH}\right)$ was generated from a standard Fenton system: $\mathrm{Fe}\left(\mathrm{NH}_{4}\right)_{2}\left(\mathrm{SO}_{4}\right)_{2} \cdot 6 \mathrm{H}_{2} \mathrm{O}(50 \mu \mathrm{L}, 0.5 \mathrm{mM})$ was added to a solution of nitrone $(50 \mathrm{mM}$, final concentration), EtOH $(50 \mu \mathrm{L})$, and $\mathrm{H}_{2} \mathrm{O}_{2}(50 \mu \mathrm{L}, 0.5 \mathrm{mM})$ in phosphate buffer (final reaction mixture was $250 \mu \mathrm{L})$.

Acknowledgment. The authors thank Collaborative Project UdelaR (Uruguay), CSIC (Spain) (Grant 2006UY0009), and Neuropharma S.A (Madrid, Spain). W.P. thanks Collaborative Project (Grant 2006UY0009) and CSIC (UdelaR) for fellowships. W.P. and P.H. are PEDECIBA students.

Supporting Information Available: Elemental analysis results for heteroarylnitrone derivatives. This material is available free of charge via the Internet at http://pubs.acs.org.

\section{References}

(1) Betteridge, D. J. What Is Oxidative Stress? Metabolism 2000, 49 (Suppl. 1), 3-8.

(2) Radi, R. Nitric Oxide, Oxidants, and Protein Tyrosine Nitration. Proc. Nat. Acad. Sci. U.S.A. 2004, 101, 4003-4008.

(3) Kowald, A.; Kirkwood, T. B. Accumulation of Defective Mitochondria through Delayed Degradation of Damaged Organelles and Its Possible Role in the Ageing of Post-Mitotic and Dividing Cells. J. Theor. Biol. 2000, 202, 145-160.

(4) Lu, C. Y.; Lee, H. C.; Fahn, H. J.; Wei, Y. H. Oxidative Damage Elicited by Imbalance of Free Radical Scavenging Enzymes Is Associated with Large-Scale mtDNA Deletions in Aging Human Skin. Mutat. Res. 1999, 423, 11-21.

(5) Hensley, K.; Robinson, K. A.; Gabbita, P.; Salsman, S.; Floyd, R. A. Reactive Oxygen Species, Cell Signaling, and Cell Injury. Free Radical Biol. Med. 2000, 28, 1456-1462.

(6) Floyd, R. A.; Hensley, K. Oxidative Stress in Brain Aging Implications for Therapeutics of Neurodegenerative Diseases. Neurobiol. Aging 2002, 23, 795-807.

(7) Yokoyama, M. Oxidant Stress and Atherosclerosis. Curr. Opin. Pharmacol. 2004, 4, 110-115.

(8) Aslan, M.; Ozben, T. Reactive Oxygen and Nitrogen Species in Alzheimer's Disease. Curr. Alzheimer Res. 2004, 1, 111-19.

(9) Floyd, R. A. Antioxidant, Oxidative Stress, and Degenerative Neurological Disorders. Proc. Soc. Exp. Biol. Med. 1999, 222, 236-245.

(10) Tabner, B. J.; Turnbull, S.; El-Agnaf, O. M. A.; Allsop, D. Formation of Hydrogen Peroxide and Hydroxyl Radicals from $\beta$ and $\alpha$-Synuclein as a Possible Mechanism of Cell Death in Alzheimer's Disease and Parkinson's Disease. Free Radical Biol. Med. 2002, 32, 1076-1083.

(11) Floyd, R. A.; Hensley, K.; Forster, M.; Kelleher-Andersson, J. A.; Wood, P. L. Nitrones, Their Value as Therapeutics and Probes To Understand Aging. Mech. Ageing Dev. 2002, 123, 1021-1031.

(12) Floyd, R. A.; Hensley, K.; Jaffery, F.; Maidt, L.; Robinson, K.; Pye, Q.; Stewart, C. Increased Oxidative Stress Brought on by ProInflammatory Cytokines in Neurodegenerative Processes and the Protective Role of Nitrone-Based Free Radical Traps. Life Sci. 1999, 65, 1893-1899.

(13) Goldstein, S.; Lestage, P. Chemical and Pharmacological Aspects of Heteroaryl-Nitrones. Curr. Med. Chem. 2000, 7, 1255-1267.

(14) Kelleher, J.; Maples, K. R.; Waterbury, L. D.; Wilcox, A. L.; Xu, Hong; Zhang,Y. K. WO 98/03496, 2002 (Centaur Pharmaceuticals, Inc., 484 Oakmead Parkway, Sunnyvale, CA 94086).

(15) Dhainaut, A.; Tizot, A.; Raimbaud, E.; Lockhart, B.; Lestage, P.; Goldstein, S. Synthesis, Structure, and Neuroprotective Properties of Novel Imidazolyl Nitrones. Dhainaut. J. Med. Chem. 2000, 43, 21652175.

(16) Villamena, F. A.; Zweier, J. L. Detection of Reactive Oxygen and Nitrogen Species by EPR Spin Trapping. Antioxid. Redox Signaling 2004, 6, 619-629.

(17) Castro, A.; Gil, C.; Encinas, A.; Castaño, T.; Porcal, W. Advances on the Synthesis and Recent Therapeutic Applications of 1,2,4-Thiadiazole Heterocycles. Bioorg. Med. Chem. 2006, 14, 1644-1652.
(18) Porcal, W.; Cerecetto, H. Pharmacological Properties of Furoxans and Benzofuroxans: Recent Developments. Mini-Rev. Med. Chem. 2005, 5, 57-71.

(19) Patai, A.; Rappoport, Z. Nitrones, Nitronates and Nitroxides; John Wiley \& Sons Ltd.: New York, 1989.

(20) Lin, Y.-i; Lang, S. A.; Petty, S. R. New Synthesis of 1,2,4-Thiadiazole. J. Org. Chem. 1980, 45, 3750-3753.

(21) Howe, R. K.; Franz, J. E. Nitrile Sulphides. Synthesis of 1,2,4Thiadiazole. J. Org. Chem. 1974, 39, 962-964.

(22) Bakulev, V. A.; Dehaen, W. Synthesis of 1,2,3-Thiadiazoles. The Chemistry of 1,2,3-Thiadiazoles; John Wiley \& Sons, Inc.: Hoboken, NJ, 2004

(23) Cerecetto, H.; Di Maio, R.; González, M.; Risso, M.; Saenz, P.; Seoane, G.; Denicola, A.; Peluffo, G.; Quijano, C.; Olea-Azar, C. 1,2,5Oxadiazole $N$-Oxide Derivatives and Related Compounds as Potential Antitrypanosomal Drugs: Structure-Activity Relationships. J. Med. Chem. 1999, 42, 1941-1950.

(24) Porcal, W.; Boiani, M.; Gerpe, A.; Merlino, A.; González, M.; Cerecetto, H. Arylethenylbenzofuroxan Derivatives as Drugs for Chagas Disease: Multigram-Batch Synthesis using Wittig-Boden Process. Org. Process Res. Dev. 2008, 12, 156-162.

(25) Marco-Contelles, J.; León, R.; de los Ríos, C.; Guglietta, A.; Terencio, J.; López, M. G.; García, A. G.; Villarroya, M. Novel Multipotent Tacrine-Dihydropyridine Hybrids with Improved Acetylcholinesterase Inhibitory and Neuroprotective Activities as Potential Drugs for the Treatment of Alzheimer's Disease. J. Med. Chem. 2006, 49, 76077610.

(26) López, G. V.; Blanco, F.; Hernández, P.; Ferreira, A.; Piro, O. E.; Batthyány, C.; González, M.; Rubbo, H.; Cerecetto, H. Second Generation of $\alpha$-Tocopherol Analogs-Nitric Oxide Donors: Synthesis, Physicochemical and Biological Characterization. Bioorg. Med. Chem. 2007, 15, 6262-6272.

(27) Rodríguez-Franco, M. I.; Fernández-Bachiller, M. I.; Pérez, C.; Hernández-Ledesma, B.; Bartolomé, B. Novel Tacrine-Melatonin Hybrids as Dual-Acting Drugs for Alzheimer Disease, with Improved Acetylcholinesterase Inhibitory and Antioxidant Properties. J. Med. Chem. 2006, 49, 459-462.

(28) Di, L.; Kerns, E. H.; Fan, K.; McConnell, O. J.; Carter, G. T. High Throughput Artificial Membrane Permeability Assay for Blood-Brain Barrier. Eur. J. Med. Chem. 2003, 38, 223-232.

(29) Ou, B.; Hampsch-Woodill, M.; Prior, R. L. Development and Validation of an Improved Oxygen Radical Absorbance Capacity Assay Using Fluorescein as the Fluorescent Probe. J. Agric. Food Chem. 2001, 49, 4619-4626.

(30) Molyneux, P. The Use of the Stable Free Radical Diphenylpicrylhydrazyl (DPPH) for Estimating Antioxidant Activity. J. Sci. Technol. 2004, 26, 211-219.

(31) Reybier, K.; Boyer, J.; Farines, V.; Camus, F.; Souchard, J.; Monje, M-C.; Bernardes-genisson, V.; Goldstein, S.; Nepveu1, F. Radical Trapping Properties of Imidazolyl Nitrones. Free Radical Res. 2006, $40,11-20$.

(32) Kim, S.; Vilela, G. V. M.; Bouajila, J.; Dias, A. G.; Cyrino, F. Z.; Bouskela, E.; Costa, P. R. R.; Nepveua, F. $\alpha$-Phenyl- $N$-tert-butyl nitrone (PBN) Derivatives: Synthesis and Protective Action against Microvascular Damages Induced by Ischemia/Reperfusion. Bioorg. Med. Chem. 2007, 15, 3572-3578.

(33) Howe, R. K.; Gruner, T. A.; Franz, J. E. Nitrile Sulfides. Synthesis of 5-Aryl-1,2,4-thiadiazole-3-carboxylates. J. Org. Chem. 1977, 42, 18131814.

(34) Castro, A.; Encinas, A.; Gil, C.; Bräse, S.; Porcal, W.; Pérez, C.; Moreno, F. J.; Martínez, M. Non ATP-Competitive Glycogen Synthase Kinase $\beta$ (GSK-3 $\beta$ ) Inhibitors: Study of Structural Requirements for Thiadiazolidinone Derivatives. Bioorg. Med. Chem. 2008, 16, 495510.

(35) Paton, R. M.; Robertson, F. M.; Ross, J. F. Nitrile Sulphides. Part 3. Thermal Fragmentation of 1,3,4-Oxathiazoles: Formation of Nitriles Sulphides in a Retro-1,3-Dipolar Cycloaddition Reaction. J. Chem. Soc., Perkin Trans. 1 1985, 151, 7-1521.

(36) Unangst, P. C.; Shrum, G. P.; Connor, D. T.; Dyer, R. D.; Schriert, D. J. Novel 1,2,4-Oxadiazoles and 1,2,4-Thiadiazoles as Dual 5-Lipoxygenase and Cyclooxygenase Inhibitors. J. Med. Chem. 1992, 35, 3691-3698.

JM8006432 